\title{
Could azithromycin play a role in the treatment of COVID-19? A review
}

\author{
Daniel Echeverria-Esnal ${ }^{1}$, Clara Martin-Ontiyuelo ${ }^{1}$, María Eugenia Navarrete-Rouco ${ }^{1}$, \\ Marta De-Antonio ${ }^{1}$, Olivia Ferrandez ${ }^{1}$, Juan Pablo Horcajada ${ }^{1}$, and Santiago Grau ${ }^{2}$ \\ ${ }^{1}$ Hospital del Mar \\ ${ }^{2}$ Hospital Universitari del Mar
}

June 9, 2020

\begin{abstract}
Azithromycin has shown antiviral and immunomodulatory actions that may be of interest in coronavirus disease-19 (COVID19). The objective of this review was to summarize the potential usefulness of azithromycin in the COVID-19. Azithromycin has shown in vitro activity against SARS-CoV-2. The potential mechanisms of action include the impairment of virus binding and of membrane fusion, endocytosis, and lysosomal protease activation due to its lysosomotropic character. Among other immunomodulatory actions, azithromycin downregulates the production of proinflammatory cytokines, maintains epithelial cell integrity and may prevent lung fibrosis. These properties, which have been related to positive clinical outcomes in other settings as influenza pneumonia, may be beneficial throughout the course of COVID-19. However, scientific evidence is still scarce. Azithromycin has mostly been studied with hydroxychloroquine/chloroquine. In outpatients, this combination showed a reduction in time to clinical recovery or need for hospitalization without safety concerns. In hospitalized patients presented an increased risk of mortality and cardiovascular events. In the few studies that assessed the efficacy of azithromycin monotherapy, a reduction in the time to clinical recovery in outpatients and a trend towards a reduction in mortality in inpatients was observed. Data on critically ill patients are lacking. The quality of data was low, as most of the studies were observational and retrospective. Azithromycin may play a role in the treatment of COVID-19. Despite the paucity of data and associated limitations, azithromycin has shown promising results that deserve further study. The upcoming clinical trials will elucidate the role of this macrolide in COVID-19.
\end{abstract}

\section{Could azithromycin play a role in the treatment of COVID-19? A review}

\section{1 - Introduction}

The severe acute respiratory syndrome coronavirus 2 (SARS-CoV-2) causes the coronavirus disease-19 (COVID-19)[1]. According to the WHO, this virus has been declared pandemic, and to date ( $7^{\text {th } J u n e), ~}$ a total of 6,799,713 diagnosed cases and 397,388 deaths have been confirmed[2].

The treatment of choice for this new disease remains unknown, so it is urgent to find effective and safe treatments. Lopinavir/ritonavir, hydroxychloroquine/chloroquine with or without azithromycin, remdesivir, tocilizumab/sarilumab, nitazoxanide, ivermectin... have been employed. Excepting from remdesivir (that in a recent clinical trial was associated with improved clinical outcomes), high quality clinical data to support the evidence (or lack of) of the rest of the treatments are still lacking[3-6].

Azithromycin has been proposed as a potential therapy for SARS-CoV-2 given its antiviral, immunomodulatory and antibacterial activity[7,8]. However, its role in the treatment of COVID-19 remains unclear.

The objective of this review was to summarize the potential usefulness of azithromycin in the treatment of COVID-19. 


\section{2-SARS-CoV-2 and COVID-19.}

SARS-CoV-2 enters the cell mainly via the human angiotensin converting enzyme 2 receptor (hACE2) through glycosylation[9]. In this process, SARS-CoV-2 is dependent upon plasmatic membrane components as gangliosides (specially GM-1), that act as attachment cofactors within lipid raft membrane platforms [9,10]. Dual recognition of both gangliosides and hACE2 by the spike protein is therefore needed[9,10]. For this purpose, viral protein displays two distinct domains: the receptor binding domain that binds to hACE2 receptor and the N-terminal domain, which binds to the ganglioside-rich domain in the membrane lipid $\operatorname{raft}[9,10]$.

Once this process has been performed, it subsequently penetrates through endocytosis[11]. Thereafter, lysosomal proteases such as cathepsins, transmembrane protease TMPRSS2 and furins must activate the fusion process by cleaving coronavirus surface spike proteins[12-14]. Without endocytosis and lysosome action the replication and infection of this virus are blocked[12].

In order to facilitate the therapeutic approach of COVID-19, a 3-stage classification system has been proposed[15]. The first stage is usually mild with non-specific symptoms and in this phase antiviral therapy may prevent progression of severity, minimize contagiousness, and reduce duration of symptoms. In the second stage patients may develop viral pneumonia 5-7 days after symptoms onset, needing in most cases hospitalization. The treatment consists of supportive measures and antiviral therapy. Although most patients are able to clear the infection in the lung, some will transition into the third and most severe stage, where the use of immunomodulatory agents may reduce systemic inflammation. In this phase, patients develop a dysfunctional immune response leading to a cytokine storm[16]. The development of such syndrome, characterized by an uncontrolled increase in the proinflammatory cytokines, has been associated with disease severity and prognosis[3,16]. This leads to multi-organ damage, including respiratory failure as a consequence of the development of lung fibrosis and acute respiratory distress syndrome (ARDS), which is the leading cause of mortality of this virus[16-18]. In the specific scenario of ARDS, cytokines may cause epithelial and capillary endothelial damage[19]. Recently, all these processes have shown to also induce endotheliitis, which may explain the systemic impaired microcirculatory function[20].

Azithromycin presents antiviral and immunomodulatory properties that could be of interest in all these stages, although specific data are lacking.

\section{3-Azithromycin.}

\section{1- Pharmacology}

Azithromycin is an antibiotic that belongs to the macrolide family used in a wide variety of bacterial diseases (respiratory tract infections, sexually transmitted diseases, etc.)[7]. Its antibacterial mechanism of action consists of the inhibition of the protein synthesis by interfering with the assembly of the 50S ribosomal subunit[7].

Azithromycin can be given either $500 \mathrm{mg}$ once daily (OD) for 3-5 days or $500 \mathrm{mg}$ on day 1 followed by 250 mg OD on days 2-5[21].

Although a $37 \%$ of oral bioavailability has been described, the extensive tissue accumulation offsets its sub-optimal absorption[7]. Its plasma protein binding is $30 \%$, with a large volume of distribution of 23$30 \mathrm{~L} / \mathrm{kg}$, mainly due to the confinement in intracellular compartments[7,22]. Azithromycin accumulates in epithelial cells, fibroblasts, lymphocytes and alveolar macrophages where, compared to serum, 400 to 1,000fold higher concentrations can be achieved[7]. This accumulation is due to its dibasic nature $\left(\mathrm{pK}_{\mathrm{a} 1} 8.1 ; \mathrm{pK}_{\mathrm{a} 2}\right.$ 8.8), which in acidic environments as intracellular lysosomes causes the protonation and trapping into the cells[23]. The ability to bind to negatively charged phospholipids in its protonated form further increases this accumulation[23]. The chemotactic drug delivery increases local drug concentrations, as blood phagocytes and other cells that migrate into infected and inflamed tissues release accumulated azithromycin[7,23]. As a consequence, azithromycin presents a long half-life of 68-79h.[23] 
All these properties explain its excellent lung tissue penetration and sustained drug concentrations[7,21,23]. Following $500 \mathrm{mg}$ OD for three days, a $\mathrm{C}_{\max }$ of $0.72-0.83 \mu \mathrm{g} / \mathrm{mL}$ in bronchial washing and $8.93-9.13 \mu \mathrm{g} / \mathrm{mL}$ in lung tissue, compared to $0.18 \mu \mathrm{g} / \mathrm{mL}$ in plasma, was found[21,24]. After a single oral dose of $500 \mathrm{mg}$, peak concentrations were $1.2-2.18 \mu \mathrm{g} / \mathrm{mL}$ in the epithelial lining fluid and $194 \mu \mathrm{g} / \mathrm{mL}$ in alveolar macrophages[22,25]. Finally, azithromycin is mainly excreted unchanged in feces[7].

\section{2- Safety data}

Azithromycin is considered to be safe, with a low risk for severe adverse effects[26]. The most frequently reported azithromycin's adverse events were gastrointestinal (diarrhea, nausea, and abdominal pain), central and peripheral nervous system (headache or dizziness), hepatotoxicity and the development of antibacterial resistance[7]. Its use, as occurs with other macrolides, has been related to QTc interval prolongation, torsade de Pointes (TdP), ventricular tachycardia and sudden cardiac death[26]. A study showing an increased risk of cardiovascular death prompted the FDA to introduce a black box warning[7]. However, in a Cochrane review, macrolide use was not associated with a higher risk of cardiac disorders when compared to placebo (OR 0.87 [95\% CI 0.54-1.40])[27]. In other systematic review and meta-analysis, macrolide use was not associated neither with an increased risk for short term arrhythmia (OR 1.19 [95\% CI 0.89-1.61]) nor 30-day mortality (OR 1.22 [95\% CI 0.94-1.60])[26]. The proarrhythmic mechanism of azithromycin is thought to be due to intracellular sodium overload[28].

\section{3 - Antiviral in vitro and animal data}

Azithromycin has shown in vitro activity against a wide variety of viruses (zika, Ebola, rhinovirus, enterovirus, influenza)[29-31]. The $50 \%$ effective concentration $\left(\mathrm{EC}_{50}\right)$ ranged between 1.23-6.59 $\mu \mathrm{M}$ depending on the virus, the cell analyzed and the multiplicity of infection (MOI) [24,30-32]. In infections caused by zika and rhinovirus azithromycin upregulated virus-induced Type I and III interferon responses reducing viral replication, suggesting that rather than its antiviral activity its immunomodulatory actions may be involved[31-35]. In mice with influenza A(H1N1) pre-treatment with azithromycin was associated with the blocking of internalization into host cells, leading to a reduction in viral load[36].

\section{4-Immunomodulatory in vitro and animal data}

Azithromycin exerts its immunomodulatory effects on different points in the inflammatory cascade, modulating cell functions and cell signaling processes[7,37,38].

In airway epithelial cells macrolides can maintain cell integrity by stabilizing the cell membrane, increasing the transepithelial electrical barrier and inducing processing of the tight junction proteins claudins and junctional adhesion molecule-A $[37,39,40]$. They can also decrease mucus hypersecretion in vitro and in vivo, even when not produced by bacteria, which may improve mucociliary clearance $[37,41,42]$. Azithromycin use directly relaxed pre-contracted airway smooth muscle cells [7].

This macrolide can decrease the hypersecretion of pro-inflammatory cytokines and chemokines by acting in many inflammatory cells as monocytes, macrophages and fibroblasts [7]. Its use has been related with a reduction of IL-1 $\beta$, IL-4, IL-5, IL-6, IL-8, IL-12, IFN- $\gamma$, IP-10, TNF- $\alpha$, and GM-CSF $[7,37,38,43]$. In alveolar macrophages, azithromycin attenuated Th-1 cell responses, shifting polarization of alveolar macrophages to their alternative activated anti-inflammatory M2 phenotype [7]. It also increased phagocytosis of apoptotic bronchial epithelial cells by macrophages [44]. In fibroblasts, macrolides have demonstrated to inhibit fibroblast proliferation, collagen production and to decrease transforming growth factor (TGF- $\beta$ ) levels [45]. In lymphocytes, azithromycin has shown to suppress CD4+ T-cell activation [46] All these findings have been demonstrated in vitro. On the contrary, azithromycin can increase the release of IL-10, an anti-inflammatory cytokine related to the reparation of the inflamed tissues $[7,37,43,45]$.

In animal models, the treatment with azithromycin reduced mortality in pneumococcal pneumonia, viral bronchiolitis and polymicrobial sepsis in mice[47-49]. These findings were found even in the setting of macrolide-resistant strains, suggesting that the immunomodulatory properties, including the aversion of cytokine storm, may explain these benefits. Azithromycin reduced the accumulation of inflammatory cells 
(macrophages, lymphocytes, and neutrophils) in bronchoalveolar lavage and in lung tissue[47]. In addition, downregulated the expression of chemokines (G-CSF, CCL3/MIP-1 $\alpha$, CCL4/MIP-1 $\beta$ ) and cytokines (IL-1 $\beta$, IL-6, IL-12, TNF- $\alpha$ and IFN- $\gamma$ ) in the lung[47,49].

In the late fibroproliferative-fibrotic phase of ARDS, azithromycin may suppress lung fibrosis[19]. In a murine model of acute lung injury caused by bleomycin, it significantly reduced fibrosis and restrictive lung function pattern[50]. Once fibrosis has been established, azithromycin could also have antifibrotic and proapoptotic effects on primary fibroblasts[51].

\section{5- Antiviral and immunomodulatory clinical efficacy}

Macrolides have shown their clinical efficacy in a wide variety of respiratory viral infections[52]. Specifically, azithromycin has been studied in influenza and Middle East Respiratory Syndrome coronavirus (MERS$\mathrm{CoV}$ ) infections[53-57]. The clinical studies of azithromycin in viral infections were summarized in Table 1.

Lee et al. concluded that in hospitalized patients with influenza A pneumonia, the addition of azithromycin to oseltamivir significantly reduced the synthesis of proinflammatory cytokines [57]. A trend towards a faster symptom resolution was noticed, with no differences in viral load change or culture negativity among groups [57]. The mean time from symptom onset to randomization was 2 days. Kakeya etal. showed that the treatment with azithromycin and oseltamivir, if initiated within $48 \mathrm{~h}$ of the onset of symptoms, in patients with mild influenza A pneumonia was associated with a significant faster resolution of fever and sore throat, without differences in the expression levels of cytokines and chemokines [56]. The low baseline values of these substances, however, may have affected the outcomes [56]. These studies are not without limitations, since they were open-label clinical trials with a small number of patients included. Subjective outcomes were analyzed, which does not seem to be the most appropriate measures in an open-label trial.

On the contrary, Martin-Loeches et al. did not show a survival benefit of macrolides in the treatment of influenza A pneumonia in critically ill patients [53]. However, this was a secondary analysis of an observational study and, importantly, both clarithromycin and azithromycin were included. Given that clarithromycin has shown less immunomodulatory activity, the potential benefits of azithromycin in this setting may have been underestimated[37,38]. In addition, the dose and duration of macrolide therapy was not described, and the treatment was initiated late in the disease (5 days).

Recently, in hospitalized patients presenting after $48 \mathrm{~h}$ of symptoms onset with influenza A pneumonia, the addition of azithromycin (initiated 6-8h after diagnosis) significantly improved meaningful clinical outcomes as length of stay or the need for respiratory support during hospitalization[55]. In patients with age [?]50 years, furthermore, a significant reduction in vasopressor use was noticed[55]. Although groups were well balanced in admission and adjusted in the multivariate model, it was a retrospective observational study so other confounding factors may have also been present.

A group of experts recommended the use of macrolides in combination with antivirals for the treatment of H1N1 influenza severe disease to reduce the systemic inflammatory response[58].

In MERS-CoV infection, macrolides were not associated with a significant benefit[54]. Again, it was a secondary analysis of an observational study, macrolides were grouped, and the dose and duration of the treatment were not reported. In addition, the sum of the patients treated with macrolides (147) was higher than stated (136) and no data concerning the time from symptom onset to treatment initiation was shown.

Only two studies reported safety data showing that azithromycin was well tolerated[56,57]. The incidence and the severity of adverse events and the rate of treatment discontinuations was similar among studied groups.

Beyond its antibacterial and potential antiviral activity, the immunomodulatory action of azithromycin may provide further clinical benefits[7]. In chronic diseases as asthma, chronic obstructive pulmonary disease, 
bronchiectasis, diffuse panbronchiolitis or Pseudomonas aeruginosa colonization, azithromycin use was associated with positive clinical outcomes and reduced risk of exacerbations $[7,59,60]$.

In the treatment of community-acquired pneumonia (CAP) its use is recommended in combination with beta-lactams, including in those admitted to the intensive care unit (ICU)[61]. For patients with bacteremic pneumococcal pneumonia, not adding a macrolide to a beta-lactam-based initial antibiotic regimen was an independent predictor of in-hospital mortality[62]. In a systematic review and meta-analysis that included 10,000 critically ill patients with CAP, macrolide use was associated with a significant reduction in mortality[42]. The immunomodulatory properties of macrolides may account for this difference, given that these benefits were even demonstrated in infections produced by macrolide-resistant strains[42,48].

In a secondary analysis of a multicenter, randomized controlled clinical trial, 235 patients were included with acute lung injury[63]. After adjusting for confounding factors, the treatment with macrolides was associated with a reduction in the time to successful ventilator discontinuation (HR 1.93 [95\% CI 1.18-3.17]) and 180day mortality (HR 0.46 [95\% CI 0.23-0.92]). Acute lung injury was mainly due to pneumonia and macrolides were started within $60 \mathrm{~h}$ of diagnosis with a median duration of 4 days (dose unknown). These differences may be due to immunomodulatory properties as were not seen with fluoroquinolones or cephalosporines. A single center, retrospective, propensity-score matched analysis included 124 patients with moderate-severe ARDS[19]. The adjunctive therapy with azithromycin was associated with a shorter time to successful discontinuation of mechanical ventilation (HR 1.74 [95\% CI 1.07-2.81]) and a reduction in 90-day mortality (HR 0.49 [95\% CI 0.27-0.87]). The main causes of ARDS were pneumonia and sepsis. Azithromycin was initiated within $24 \mathrm{~h}$ of diagnosis and used for 5 days (dose unknown).

\section{4-Azithromycin and SARS-CoV-2}

\section{1 - In vitro data}

In Vero E6 cells with a MOI of 0.002, azithromycin showed an $\mathrm{EC}_{50}$ of $2.12 \mu \mathrm{M}$, an $\mathrm{EC}_{90}$ of $8.65 \mu \mathrm{M}$ and a $50 \%$ cytotoxic concentration $>40 \mu \mathrm{M}$, with a selectivity index $>19[64]$. On the contrary, in another study performed in Vero E6 cells with a MOI of 0.25 azithromycin alone did not show any antiviral activity[65]. However, the combination of hydroxychloroquine at $5 \mu \mathrm{M}$ with azithromycin at 5 and $10 \mu \mathrm{M}$ was found to be synergistic and significantly inhibited viral replication[65]. The different MOI among the two studies may have accounted for these differences. Anyway, caution is advised when interpreting these results given the different MOI, cell lines, incubation times and analytical methods[24].

Azithromycin used at conventional doses could achieve therapeutic concentrations in the lung to be effective against SARS-CoV-2[24,65]. Based on previous described pharmacokinetic andin vitro data, $\mathrm{C}_{\max } / \mathrm{EC}_{50}$ ratios of 91.5 in alveolar macrophages or 4.3 in lung tissue could be achieved[24,65]. In the study of Andreani et al. authors concluded that the observed synergy was achieved at concentrations achieved in vivo in the lungs[65].

Other macrolides have also demonstrated in vitro antiviral activity against SARS-CoV-2, as bafilomycin A decreased the entry of pseudovirions by $99 \%$ compared to the control group[11].

In Figure 1, the proposed antiviral and immunomodulatory mechanisms of action of azithromycin in the treatment of COVID-19 were described.

Azithromycin could act in SARS-CoV-2 binding to respiratory cells. Its intracellular accumulation led to an increase in the $\mathrm{pH}$ that may impair trans-Golgi network (TGN) and lysosome functions [12,45]. Poschet et al . found that the treatment of CF bronchial epithelial cells with $100 \mu \mathrm{M}$ for $1 \mathrm{~h}$ and $1 \mu \mathrm{M}$ of azithromycin for $48 \mathrm{~h}$ led to an increase in TGN pH from $6.1 \pm 0.2$ to $6.7 \pm 0.1$ [45]. Authors postulated that this increase in $\mathrm{pH}$ in TGN may alter glycosylation of hACE2 and other proteins [45]. Using molecular dynamic simulations, another direct antiviral mechanism of this macrolide was theorized [9]. Azithromycin resulted in a ganglioside-mimic given its similar volume and analogous chemical features than GM1. Since the spike protein of SARS-CoV-2 displays a ganglioside-binding site, azithromycin might inhibit SARS-CoV-2 infection by binding to this site. This would prevent the virus spike protein to reach gangliosides on the host plasma 
membrane that are involved in SARS-CoV-2 pathogenesis [9]. Ulrich et al . concluded that azithromycin may have antiviral activity against SARS-CoV-2 by interfering in the spike protein/CD147 interaction or CD147 expression[66].

Endocytosis and fusion process activation by lysosomes are essential for SARS-CoV-2 entry and infection [12]. The increase in the lysosomal $\mathrm{pH}$ by azithromycin may alter the endocytosis process $[7,67,68]$. Furthermore, the impairment of lysosomal proteases such as cathepsins and furin may also play a role $[7,45,67,69]$. Poschet et al found that $100 \mu \mathrm{M}$ of azithromycin could normalize the excessive processing and activation of furin [45]. Given that SARS-CoV-2 has been shown to present a furin-like cleavage site in the spike protein, the reduction in the activation of furin by azithromycin could prevent the entry of SARS-CoV-2 into human epithelial cells $[13,70]$.

\section{2 - Clinical data}

All available evidence on the use of azithromycin in the treatment of COVID-19 was summarized in Table 2.

In March, Gautret et al. showed that the early treatment either with hydroxychloroquine presented superior virological clearance compared to standard of care[8]. Moreover, the addition of azithromycin further improved the activity of hydroxychloroquine alone. However, only 6 patients were treated with hydroxychloroquine and azithromycin.

Based on this study and in vitro data showing synergic activity, some hospitals started to spread the use of this combination. Nevertheless, the International Society of Antimicrobial Chemotherapy raised concerns as they believed that did not meet the society's expected standard[71].

These authors subsequently expanded the number of included patients evaluating this combination[72,73]. They included those admitted to the infectious disease ward or treated in day-care hospital, so disease presentation was mild. Overall, clinical and viral outcome was positive. On the contrary, Molina et al. challenged these results in sicker patients as this strategy was not associated with any clinical benefit or antiviral activity[74]. In all these studies, unfortunately, a control group was lacking.

Mahevas et al. assessed the efficacy of hydroxychloroquine in 173 hospitalized patients showing no effect in any outcomes[75]. Patients with organ failure, ARDS or ICU at admission and those treated with other experimental therapies (remdesivir, tocilizumab or lopinavir/ritonavir) were excluded. Given that the objective of the study was the evaluation of the efficacy of hydroxychloroquine, the outcomes of azithromycin alone or in combination were not analyzed. Azithromycin was administered in 15 (18\%) patients in the treatment group and $26(29 \%)$ in the control group. Among those treated with azithromycin alone, 5 (19.2 $\%)$ died and $6(23.1 \%)$ were transferred to the ICU. These patients, however, were not further analyzed nor included in the propensity-score analysis and no data about their baseline and clinical demographics were detailed.

In patients hospitalized at Veterans Health Administration medical centers, Magagnoli et al. demonstrated a higher risk of mortality in hospitalized patients treated with hydroxychloroquine alone after propensity-score adjustment [76]. However, this finding was not observed with combination therapy. The risk of mechanical ventilation was similar among hydroxychloroquine alone (aHR 1.19 [95\% CI 0.78-1.82]) and hydroxychloroquine/azithromycin groups (aHR 1.09 [95\% CI 0.72-1.66]) when compared to the no-hydroxychloroquine group. The use of other therapies was not assessed and no information about ICU status at admission was reported.

Geleris et al. included 1,085 hospitalized patients in a propensity-score matched analysis in New York[77]. Patients who died or were intubated within 24 hours after presentation were excluded. Azithromycin was used in both groups (59.9\% in the treatment group and $37.2 \%$ in the control group). Other agents as tocilizumab/sarilumab or remdesivir were allowed (data on corticosteroids was not shown). In the multivariate analysis hydroxychloroquine or azithromycin use was not associated with the composite primary endpoint. 
Rosenberg et al. showed a trend towards reduced mortality in the azithromycin alone group, after adjusting for multiple factors[78]. Unlike other studies, patients admitted to the ICU were not excluded. In the estimated direct-adjusted model, 21-day mortality was $22.5 \%$ (95\% CI 19.7-25.1) in the combination group, $18.9 \%$ (95\% CI 14.3-23.2) in the hydroxychloroquine alone group, $10.9 \%$ (95\% CI 5.8-15.6) in the azithromycin group and $17.8 \%$ (95\% CI, 11.1-23.9) in the control group. When hydroxychloroquine and azithromycin monotherapy groups were compared, no differences were observed in mortality (aHR 1.92 [95\% CI 0.99-3.74]), although it was in the limit of significance.

Another pre-print study showed potential benefits of azithromycin alone, but unfortunately was withdrawn.

Recently, Guérin et al. assessed the time to clinical recovery of azithromycin and its combination with hydroxychloroquine compared to standard of care in outpatients[79]. Both treatments accelerated recovery both in the global cohort and after adjusting in a case-control analysis. No significant differences were found when azithromycin monotherapy and combination therapy were compared $(\mathrm{P}=0.26)$.

Barbosa et $a l$. evaluated the combination therapy in the need for hospitalization in outpatients[80]. Patients with flu-like symptoms were referred to telemedicine service, where combination therapy was offered. Those who refused to initiate this treatment were considered the control group. The treatment group was associated with a reduction in the need for hospitalization of $3.5 \%$. Moreover, among those in the treatment group, patients treated before day 7 of symptoms onset required less hospitalization $(1.17 \%$ vs. $3.2 \%, \mathrm{P}<0.001)$.

To date, 36 clinical trials are recruiting patients to evaluate azithromycin in a wide variety of scenarios (outpatients, combined with hydroxychloroquine or other drugs, ICU...).

\section{2- Safety data}

In the context of COVID-19, the potential cardiotoxicity of azithromycin has been a concern. Hydroxychloroquine is known to prolong the QTc interval, and the combination of these drugs has been associated with an increased risk of adverse events[78].

Several reports have shown the higher risk of QTc prolongation with the use of hydroxychloroquine alone or in combination with macrolides[28,76,81-85]. Furthermore, these treatments have been related to a higher risk of developing cardiac arrest or ventricular arrythmia. An incidence of $0.4 \%$ in the development of TdP was described with the use of combination therapy[85]. This abnormal findings appear to be developed at day $3-4$ of the treatment $[28,75,82]$. The main data concerning the cardiovascular risk of the treatment with azithromycin (alone or in combination) were detailed in Table 3.

In patients with mild disease, overall azithromycin and its combination with hydroxychloroquine were well tolerated. Million et al . reported a $2.4 \%$ incidence of adverse events, mainly gastrointestinal with a very low rate of QTc interval prolongation[73]. None of the reasons for treatment discontinuation in $3(0.28 \%)$ patients were cardiovascular. Guerin et al . reported no cardiovascular events[79]. In the study of Barbosa et al. the main adverse effect was diarrhea, but $12.9 \%$ of patients presented diarrhea before the onset of the treatment.[80] No cardiovascular adverse effects were recorded.

Rosenberg et $a l$. reported a higher risk of cardiac arrest and arrhythmia with the use of hydroxychloroquine alone or in combination[78]. Patients treated with hydroxychloroquine alone presented a higher risk of cardiac arrest (aOR 2.97 [95\% CI 1.56-5.64]) than those treated with azithromycin. This difference among the two treatments was maintained even in patients without mechanical ventilation (aOR 3.01 [95\% CI 1.07-8.51]), excluding other factors for adverse events as severity. Azithromycin alone did not increase the risk of cardiovascular adverse events compared to standard of care group. This was also shown in another study where the addition of azithromycin to hydroxychloroquine increased the risk of 30-day cardiovascular mortality[86]. In this study, however, in the other analyzed outcomes no differences were found and, in addition, when accounting by the standard Bonferroni correction of multiple comparison, only chest pain/angina remained statistically significant[87].

Other factors may also play a role in the development of these adverse events. The use of loop diuretic drugs, 
baseline QTc [?] $450 \mathrm{~ms}$, more than 2 systemic inflammatory response syndrome criteria and intensive care status at time of test were associated with a higher risk of developing QTc [?] $500 \mathrm{~ms}[81]$. The use of other medications that prolong the QTc, electrolyte disturbances, female gender, older age, personal or family history of QT interval prolongation and other diagnoses as chronic renal failure, cardiac heart failure, structural heart disease, genetic polymorphisms and congenital long QT syndrome are other potential risk factors $[28,88]$.

Some algorithms have been proposed to try to minimize the associated risks[88]. A careful revision of the history of the patient to detect any diseases with an increased risk of QTc prolongation, together with the assessment of potential electrolyte disturbances and the presence of other QTc prolonging medications and their interactions is advised before initiating the treatment[88]. An electrocardiogram and electrolyte monitoring are recommended during the first days of therapy to detect any potential alterations[88].

\section{Discussion}

Azithromycin presents numerous characteristics that could confer a clinical benefit in the treatment of COVID-19. Its potential antiviral, immunomodulatory and antibacterial properties could be of interest in all the three proposed stages of COVID-19. However, despite all these promising benefits, the use of azithromycin in the treatment of SARS-CoV-2 pneumonia remains unclear.

Unfortunately, studies carried out on the potential value of azithromycin have been mostly accompanied by its prescription in association with hydroxychloroquine/chloroquine. This constitutes a great limitation and hampers the assessment of the potential benefits of the macrolide, especially given the recent negative benefit-risk balance of hydroxychloroquine and chloroquine.

In other viral infections as influenza, although the available evidence is of low quality, azithromycin has proven to be useful when given early in the disease. In the early stage of COVID-19, where the use of antivirals might be indicated, azithromycin could reduce the number of complications, including the need for hospitalization. However, most studies have focused on advanced forms of the disease, so outpatients have been misrepresented.

Gautret et $a l$. assessed the early treatment with hydroxychloroquine and azithromycin in patients with mild disease (mostly asymptomatic or with upper respiratory tract infections) [8]. This was the first study assessing the efficacy of this combination. Although a higher virological clearance was observed, this assumption should be taken with caution given the limitations. This was a non-randomized open-label clinical trial that only included 36 patients. Only 6 patients were treated with combination therapy, without adequate controls. From a total of 26 patients treated with hydroxychloroquine, 6 were lost in follow-up: 3 because were transferred to ICU, 1 died, 1 decided to leave and 1 stopped the treatment due to nausea. Patients in the treatment group had higher viral loads, so a likely benefit was easier to demonstrate[5]. Finally, baseline clinical data were lacking, and no clinical outcomes or safety data were reported. Thereafter, Gautret et al . and Million et $a l$. showed positive results without significant safety issues when given this combination in a higher number of mild patients at day 5-6 of the symptom onset[72,73]. Again, the lack of control group, however, prevents the attribution of any benefits to this therapy.

A recent review concluded that this combination should be used in symptomatic high-risk outpatients, mainly based on the study performed by Barbosa et al, where although treated patients were sicker presented a reduction in the need of hospitalization[87]. However, this is a pre-print study open-label study and was performed by a telemedicine healthcare team, so it may not be applicable to other settings. The study of Guerin et al . seems to confirm the potential benefit of this strategy[79]. Interestingly, this study showed that azithromycin alone presented similar outcomes when compared to combination therapy[79]. Again, it was a pre-print study with a small sample size and the outcome was a subjective measure. Other limitations include that the time of treatment initiation from symptom onset was day 1 in $41 \%$ of patients, while the rest initiated within 15 days and 1 in the azithromycin alone group in day 40. The lack of data concerning the viral load is another limitation that prevents the evaluation of the potential antiviral activity of azithromycin. Azithromycin was well tolerated in these studies with no associated cardiovascular events, suggesting that 
these toxicities may be more evident in sicker patients[72,73,79,80,87].

The use of azithromycin in the first stage of COVID-19 has been therefore poorly studied, with a low number of patients included and studies with many flaws. However, the available evidence suggests a potential benefit of its use alone or in combination that requires further study.

Based on the first study of Gautret et al ., combination therapy began to be used in the second stage of COVID-19[8]. After adjusting for confounding factors, this combination was associated with an increased risk of mortality and adverse events[78]. Other studies also reported a lack of benefit of the treatment with hydroxychloroquine[75,77]. Again, these findings must be interpreted with caution given the many limitations of the included studies. Some of them presented low sample sizes so were underpowered. None of the studies was a placebo controlled randomized clinical trial (all were observational studies), so they were not designed to assess the efficacy of these regimens. Despite the efforts to control for confounding factors, in observational studies even the best adjustment methods can miss major systematic biases[89]. Among confounding factors, the use of other therapies such as antivirals, immunomodulators (specially glucocorticoids) and anticoagulation therapy were not either described or adequately controlled. This is of upmost importance given recent evidence showing clinical benefits with the use of remdesivir, corticoids or anticoagulation therapy[4,90,91]. Another important issue is that azithromycin was given alone, when reported, in 29-37\% of patients in the control groups. Given the potential benefits associated with this macrolide, this may have also been a potential confounding factor.

All these studies have evaluated robust and objective clinical outcomes as in-hospital mortality or need for intubation. However, other outcomes such as time to clinical recovery, time to symptom resolution or length of stay were not analyzed and could offer another vision of the treatment.

The time from the onset of symptoms until the initiation of treatment is another important issue. Only one study reported these data and treatments were initiated late (8 days)[75]. This could have underestimated combination treatment efficacy as was not initiated when it should be more active. One might think that by this time azithromycin should show clinical benefits since there might already be some hyperinflammation. However, patients included in these studies presented mild disease with a low incidence of comorbidities, which prevents demonstrating the potential benefit of azithromycin in this setting.

Three studies analyzed the effect of this macrolide alone. Geleris etal . did not find any clinical benefit with the use of this macrolide[77]. However, they did not demonstrate any clinical benefit either with remdesivir, which has recently shown significant clinical benefits in a randomized controlled trial[4]. This fact raises concerns about the conclusions of this study, given that both azithromycin and remdesivir were assessed as potential covariates without showing specific data of patients that received them[77]. In the study of Rosenberg et al . reporting data on the sickest patients to date, this macrolide was associated with a trend towards reduction in mortality[78]. Another pre-print study showing potential benefits with azithromycin alone was withdrawn. As commented when evaluating the outcomes with combination therapy, caution is advised given the multiple limitations. As observational studies, other unmeasured confounding factors may have been present[78].

In the second phase of COVID-19, the combination therapy, after adjusting for confounding factors, has been associated with an unacceptable risk of cardiovascular toxicity and arrhythmias. However, patients in the treatment groups were sicker, which may have affected safety outcomes despite adjusting for confounding variables. The rate of treatment discontinuation was not systematically reported, and treatment regimens were different across the studies.

Azithromycin, without concomitant hydroxychloroquine/chloroquine treatment, does not seem to confer the same risk of adverse events[27]. This may suggest that the main driver of toxicity in this setting is the use of other drugs and not azithromycin by itself. If this macrolide is considered, when possible oral route should be preferred due to lower peak levels that have been associated to a lower risk of cardiac toxicity[92].

Despite all the limitations, the treatment with hydroxychloroquine and azithromycin does not seem to offer 
any benefit in the second stage of COVID-19 and, on the contrary, has been associated with an increased risk of adverse effects and mortality. Therefore, until more data are available, its use should not be recommended outside from clinical trials. Azithromycin alone in addition to standard of care may provide additional benefits without safety concerns that need to be validated in clinical trials.

The third and more severe stage of COVID-19 is characterized by the development of hyperinflammation and cytokine storm. In this setting, other immunomodulatory therapies as corticosteroids or anti-IL6 have been proposed[18,90]. Azithromycin's immunomodulatory effects may therefore play a role, given its ability to reduce cytokine expression among other properties. In other diseases as CAP, the immunomodulatory activity of azithromycin observed in vitro and in animal models has been demonstrated in high-quality clinical studies without safety issues. Furthermore, the potential benefits of azithromycin in severe lung injury and ARDS when initiated early in the disease have been demonstrated[19,63]. These benefits may be translated into patients with COVID-19, as a recent pre-print study showed that the cytokine profile in plasma (IL-1 $\beta$, IL-1RA, IL-6, IL-8, IL-18, and TNF $\alpha$ ) of severe COVID-19 patients did not differ from that found in other ARDS and sepsis of other causes[93]. In addition, its potential antifibrotic activity may be useful in ARDS or in patients who develop lung fibrosis. Recent evidence has demonstrated that COVID-19 can cause microvascular damage with endotheliitis, suggesting that therapies that stabilize the endothelial cells may be of interest[20]. Azithromycin may be useful since it has shown to stabilize and maintain the epithelial cells integrity[7].

In spite of all these potential benefits in critically ill patients, these patients have also been misrepresented. In all but one of the previous studies, patients admitted to the ICU at the time of treatment initiation were excluded. This is important since, at least in CAP, the beneficial immunomodulatory protective effect seems to be more evident in the most severe patients[53]. Unfortunately, the its potential usefulness in COVID-19 induced lung injury, ARDS or fibrosis remains unknown.

Concerning its bacterial activity, a recent meta-analysis showed that $7 \%$ (14\% if admitted to ICU) presented bacterial co-infections, which was lower than with other viruses like influenza[94].Mycoplasma pneumoniae was found in $42 \%$ of confirmed co-infections, although they were diagnosed serologically through the detection of IgM, which may have overestimated the rate of infections[94]. Unlike in influenza, where this macrolide reduced the rate of bacterial superinfections, the potential antibacterial benefit of azithromycin in the setting of COVID-19 has not been studied[55].

Azithromycin has demonstrated clinical benefits in other settings due to its antiviral and immunomodulatory action. However, in the treatment of COVID-19 it has been poorly studied, mainly in combination with hydroxychloroquine. Moreover, it has been studied in a very specific subgroup of patients, with other subgroups where it may offer the greatest clinical benefits being misrepresented. Although the paucity of data and associated limitations, azithromycin has shown promising results that deserve further study and may play a role in the treatment of COVID-19. The upcoming clinical trials will show whether this macrolide, alone or in combination, may be useful and which patients benefit most from it in the treatment of COVID-19.

Acknowledgements : We would like to thank Inés de Mena Urrutia for the thoughtful revision of the manuscript.

Conflict of interest: None to declare.

Funding: This research did not receive any specific grant from funding agencies in the public, commercial, or not-for-profit sectors.

\section{References}

[1] Guan W, Ni Z, Hu Y, Liang W, Ou C, He J, et al. Clinical Characteristics of Coronavirus Disease 2019 in China. N Engl J Med 2020;382:1708-20. doi:10.1056/NEJMoa2002032.

[2] WHO situation report.Coronavirus disease (COVID-19) Highlights. Available on 
https://www.who.int/docs/default-source/coronaviruse/situation-reports/20200607-covid-19-sitrep139.pdf?sfvrsn=79dc6d08_2.

[3] Sanders JM, Monogue ML, Jodlowski TZ, Cutrell JB. Pharmacologic Treatments for Coronavirus Disease 2019 (COVID-19): A Review. JAMA - J Am Med Assoc 2020;323:1824-36. doi:10.1001/jama.2020.6019.

[4] Beigel JH, Tomashek KM, Dodd LE, Mehta AK, Zingman BS, Kalil AC, et al. Remdesivir for the Treatment of Covid-19 - Preliminary Report. N Engl J Med 2020:NEJMoa2007764. doi:10.1056/NEJMoa2007764.

[5] McCreary EK, Pogue JM. Coronavirus disease 2019 treatment: A review of early and emerging options. Open Forum Infect Dis 2020;7:1-11. doi:10.1093/ofid/ofaa105.

[6] Caly L, Druce JD, Catton MG, Jans DA, Wagstaff KM. The FDA-approved Drug Ivermectin inhibits the replication of SARS-CoV-2 in vitro. Antiviral Res 2020:104787. doi:10.1016/j.antiviral.2020.104787.

[7] Parnham MJ, Haber VE, Giamarellos-Bourboulis EJ, Perletti G, Verleden GM, Vos R. Azithromycin: Mechanisms of action and their relevance for clinical applications. Pharmacol Ther 2014;143:22545.doi:10.1016/j.pharmthera.2014.03.003.

[8] Gautret P, Lagier J-C, Parola P, Hoang VT, Meddeb L, Mailhe M, et al. Hydroxychloroquine and azithromycin as a treatment of COVID-19: results of an open-label non-randomized clinical trial. Int J Antimicrob Agents 2020:105949. doi:10.1016/j.ijantimicag.2020.105949.

[9] Fantini J, Chahinian H, Yahi N. nSynergistic antiviral effect of hydroxychloroquine and azithromycin in combination against SARS-CoV-2: what molecular dynamics studies of virus-host interactions reveal. Int J Antimicrob Agents 2020:106020. doi:10.1016/j.ijantimicag.2020.106020.

[10] Fantini J, Di Scala C, Chahinian H, Yahi N. Structural and molecular modelling studies reveal a new mechanism of action of chloroquine and hydroxychloroquine against SARS-CoV-2 infection. Int J Antimicrob Agents 2020:105960. doi:10.1016/j.ijantimicag.2020.105960.

[11] Ou X, Liu Y, Lei X, Li P, Mi D, Ren L, et al. Characterization of spike glycoprotein of SARS-CoV-2 on virus entry and its immune cross-reactivity with SARS-CoV. Nat Commun 2020; 11: 1620.

[12] Zhou D, Dai S-M, Tong Q. COVID-19: a recommendation to examine the effect of hydroxychloroquine in preventing infection and progression. J Antimicrob Chemother 2020, in press.

[13] Coutard B, Valle C, de Lamballerie X, Canard B, Seidah NG, Decroly E. The spike glycoprotein of the new coronavirus 2019-nCoV contains a furin-like cleavage site absent in $\mathrm{CoV}$ of the same clade. Antiviral Res 2020;176:104742. doi:10.1016/j.antiviral.2020.104742.

[14] Rabi FA, Al Zoubi MS, Al-Nasser AD, Kasasbeh GA, Salameh DM. Sars-cov-2 and coronavirus disease 2019: What we know so far. Pathogens 2020;9:1-14. doi:10.3390/pathogens9030231.

[15] Siddiqi HK, Mehra MR. COVID-19 Illness in Native and Immunosuppressed States: A ClinicalTherapeutic Staging Proposal. J Heart Lung Transplant 2020; 39: 405-407

[16] Tay MZ, Poh CM, Rénia L, MacAry PA, Ng LFP. The trinity of COVID-19: immunity, inflammation and intervention. Nat Rev Immunol 2020:1-12. doi:10.1038/s41577-020-0311-8.

[17] Mehta P, McAuley DF, Brown M, Sanchez E, Tattersall RS, Manson JJ, et al. COVID-19: consider cytokine storm syndromes and immunosuppression. Lancet 2020; 395: 1033-34.

[18] Xu X, Han M, Li T, Sun W, Wang D, Fu B, et al. Effective treatment of severe COVID-19 patients with tocilizumab. Proc Natl Acad Sci 2020;117:202005615. doi:10.1073/pnas.2005615117.

[19] Kawamura K, Ichikado K, Takaki M, Eguchi Y, Anan K, Suga M. Adjunctive therapy with azithromycin for moderate and severe acute respiratory distress syndrome: a retrospective, propensity scorematching analysis of prospectively collected data at a single center. Int J Antimicrob Agents 2018;51:918-24. doi:10.1016/j.ijantimicag.2018.02.009. 
[20] Varga Z, Flammer AJ, Steiger P, Haberecker M, Andermatt R, Zinkernagel AS, et al. Endothelial cell infection and endotheliitis in COVID-19. Lancet 2020;395:1417-8. doi:10.1016/S0140-6736(20)30937-5.

[21] Danesi R, Lupetti A, Barbara C, Ghelardi E, Chella A, Malizia T, et al. Comparative distribution of azithromycin in lung tissue of patients given oral daily doses of 500 and $1000 \mathrm{mg}$. J Antimicrob Chemother 2003;51:939-45. doi:10.1093/jac/dkg138.

[22] Lucchi M, Damle B, Fang A, de Caprariis PJ, Mussi A, Sanchez SP, et al. Pharmacokinetics of azithromycin in serum, bronchial washings, alveolar macrophages and lung tissue following a single oral dose of extended or immediate release formulations of azithromycin. J Antimicrob Chemother 2008;61:884-91. doi:10.1093/jac/dkn032.

[23] Zheng S, Matzneller P, Zeitlinger M, Schmidt S. Development of a population pharmacokinetic model characterizing the tissue distribution of azithromycin in healthy subjects. Antimicrob Agents Chemother 2014;58:6675-84. doi:10.1128/AAC.02904-14.

[24] Damle B, Vourvahis M, Wang E, Leaney J, Corrigan B. Clinical Pharmacology Perspectives on the Antiviral Activity of Azithromycin and Use in COVID-19. Clin Pharmacol Ther. 2020, in press.

[25] Baldwin DR, Wise R, Andrews JM, Ashby JP, Honeybourne D. Azithromycin concentrations at the sites of pulmonary infection. Eur Respir J 1990;3:886-90.

[26] Gorelik E, Masarwa R, Perlman A, Rotshild V, Muszkat M, Matok I. Systematic review, meta-analysis, and network meta-analysis of the cardiovascular safety of macrolides. Antimicrob Agents Chemother 2018;62. doi:10.1128/AAC.00438-18.

[27] Hansen MP, Scott AM, Mccullough A, Thorning S, Aronson JK, Beller EM, et al. Adverse events in people taking macrolide antibiotics versus placebo for any indication. Cochrane Database Syst Rev 2019; 1: CD011825.

[28] Saleh M, Gabriels J, Chang D, Kim BS, Mansoor A, Mahmood E, et al. The Effect of Chloroquine, Hydroxychloroquine and Azithromycin on the Corrected QT Interval in Patients with SARS-CoV-2 Infection. Circ Arrhythmia Electrophysiol 2020:CIRCEP.120.008662. doi:10.1161/CIRCEP.120.008662.

[29] Madrid PB, Panchal RG, Warren TK, Shurtleff AC, Endsley AN, Green CE, et al. Evaluation of Ebola Virus Inhibitors for Drug Repurposing. ACS Infect Dis 2016;1:317-26. doi:10.1021/acsinfecdis.5b00030.

[30] Zheng S, Meng X, Huang Q, et al . Spiramycin and Azithromycin, Safe for Administration to Children, Exert Antiviral Activity Against Enterovirus A71 in Vitro and in Vivo. Int J Antimicrob Agents; 53:362-69.

[31] Li C, Zu S, Deng Y-Q, Li D, Parvatiyar K, Quanquin N, et al. Azithromycin Protects against Zika Virus Infection by Upregulating Virus-Induced Type I and III Interferon Responses. Antimicrob Agents Chemother 2019; 63: e00394-19.

[32] Iannetta M, Ippolito G, Nicastri E. Azithromycin Shows Anti-Zika Virus Activity in Human Glial Cells. Antimicrob Agents Chemother 2017;61. doi:10.1128/aac.01152-17.

[33] Schögler A, Kopf BS, Edwards MR, Johnston SL, Casaulta C, Kieninger E, et al. Novel antiviral properties of azithromycin in cystic fibrosis airway epithelial cells. Eur Respir J 2015;45:428-39. doi:10.1183/09031936.00102014.

[34] Gielen V, Johnston SL, Edwards MR, Edwards CMR. Azithromycin induces anti-viral responses in bronchial epithelial cells. Eur Respir J Eur Respir J 2010;36:646-54. doi:10.1183/09031936.00095809.

[35] Menzel M, Akbarshahi H, Bjermer L, Uller L. Azithromycin induces anti-viral effects in cultured bronchial epithelial cells from COPD patients OPEN. Sci rep 2016; 6: 28698.

[36] Tran DH, Sugamata R, Hirose T, Suzuki S, Noguchi Y, Sugawara A, et al. Azithromycin, a 15-membered 
macrolide antibiotic, inhibits influenza $\mathrm{A}(\mathrm{H} 1 \mathrm{N1})$ pdm09 virus infection by interfering with virus internalization process. J Antibiot (Tokyo) 2019;72:759-68. doi:10.1038/s41429-019-0204-x.

[37] Kanoh S, Rubin BK. Mechanisms of Action and Clinical Application of Macrolides as Immunomodulatory Medications. Clin Microbiol Rev 2010;23:590-615. doi:10.1128/CMR.00078-09.

[38] Zimmermann P, Ziesenitz VC, Curtis N, Ritz N. The immunomodulatory effects of macrolides-A systematic review of the underlying mechanisms. Front Immunol 2018;9:302. doi:10.3389/fimmu.2018.00302.

[39] Arason AJ, Joelsson JP, Valdimarsdottir B, Sigurdsson S, Gudjonsson A, Halldorsson S, et al. Azithromycin induces epidermal differentiation and multivesicular bodies in airway epithelia. Respir Res 2019;20:129. doi:10.1186/s12931-019-1101-3.

[40] Asgrimsson V, Gudjonsson T, Gudmundsson GH, Baldursson O. Novel effects of azithromycin on tight junction proteins in human airway epithelia. Antimicrob Agents Chemother 2006;50:1805-12. doi:10.1128/AAC.50.5.1805-1812.2006.

[41] Shimizu T, Shimizu S. Azithromycin inhibits mucus hypersecretion from airway epithelial cells. Mediators Inflamm 2012;2012:1-6. doi:10.1155/2012/265714.

[42] Sligl WI, Asadi L, Eurich DT, Tjosvold L, Marrie TJ, Majumdar SR. Macrolides and mortality in critically Ill patients with community-acquired pneumonia: A systematic review and meta-analysis. Crit Care Med 2014;42:420-32. doi:10.1097/CCM.0b013e3182a66b9b.

[43] Vrančić M, Banjanac M, Nujić K, Bosnar M, Murati T, Munić V, et al. Azithromycin distinctively modulates classical activation of human monocytes in vitro. Br J Pharmacol 2012;165:1348-60. doi:10.1111/j.14765381.2011.01576.x.

[44] Hodge S, Hodge G, Brozyna S, Jersmann H, Holmes M, Reynolds PN. Azithromycin increases phagocytosis of apoptotic bronchial epithelial cells by alveolar macrophages. Eur Respir J 2006;28:486-95. doi:10.1183/09031936.06.00001506.

[45] Poschet JF, Perkett EA, Timmins GS, Deretic V, Co-Corresponding \#, Timmins G. Azithromycin and ciprofloxacin have a chloroquine-like effect on respiratory epithelial cells. bioRxiv 2020.03.29.008631; doi: https://doi.org/10.1101/2020.03.29.008631.

[46] Ratzinger F, Haslacher H, Poeppl W, Hoermann G, Kovarik JJ, Jutz S, et al. Azithromycin suppresses CD4 + T-cell activation by direct modulation of mTOR activity. Sci Rep 2014;4:1-10. doi:10.1038/srep07438.

[47] Beigelman A, Mikols CL, Gunsten SP, Cannon CL, Brody SL, Walter MJ. Azithromycin attenuates airway inflammation in a mouse model of viral bronchiolitis. Respir Res 2010;11:1-11. doi:10.1186/14659921-11-90.

[48] Karlström A, Heston SM, Boyd KL, Tuomanen EI, McCullers JA. Toll-like receptor 2 mediates fatal immunopathology in mice during treatment of secondary pneumococcal pneumonia following influenza. J Infect Dis 2011;204:1358-66. doi:10.1093/infdis/jir522.

[49] Patel A, Joseph J, Periasamy H, Mokale S. Azithromycin in combination with ceftriaxone reduces systemic inflammation and provides survival benefit in a murine model of polymicrobial sepsis. Antimicrob Agents Chemother 2018;62:1-13. doi:10.1128/AAC.00752-18.

[50] Wuyts WA, Willems S, Vos R, Vanaudenaerde BM, De Vleeschauwer SI, Rinaldi M, et al. Azithromycin reduces pulmonary fibrosis in a bleomycin mouse model. Exp Lung Res 2010;36:602-14. doi:10.3109/01902148.2010.492895.

[51] Krempaska K, Barnowski S, Gavini J, Hobi N, Ebener S, Simillion C, et al. Azithromycin has enhanced effects on lung fibroblasts from idiopathic pulmonary fibrosis (IPF) patients compared to controls. Respir Res 2020; 21: 25. doi:10.1186/s12931-020-1275-8. 
[52] Min JY, Jang YJ. Macrolide therapy in respiratory viral infections. Mediators Inflamm 2012;2012. doi: $10.1155 / 2012 / 649570$.

[53] Martín-Loeches I, Bermejo-Martin JF, Vallés J, Granada R, Vidaur L, Vergara-Serrano JC, et al. Macrolide-based regimens in absence of bacterial co-infection in critically ill H1N1 patients with primary viral pneumonia. Intensive Care Med 2013;39:693-702. doi:10.1007/s00134-013-2829-8.

[54] Arabi YM, Deeb AM, Al-Hameed F, Mandourah Y, Almekhlafi GA, Sindi AA, et al. Macrolides in critically ill patients with Middle East Respiratory Syndrome. Int J Infect Dis 2019;81:184-90. doi:10.1016/j.ijid.2019.01.041.

[55] Ishaqui AA, Khan AH, Sulaiman SAS, Alsultan MT, Khan I, Naqvi AA. Assessment of efficacy of Oseltamivir-Azithromycin combination therapy in prevention of Influenza-A (H1N1)pdm09 infection complications and rapidity of symptoms relief. Expert Rev Respir Med 2020;14:533-41. doi:10.1080/17476348.2020.1730180.

[56] Kakeya H, Seki M, Izumikawa K, Kosai K, Morinaga Y, Kurihara S, et al. Efficacy of Combination Therapy with Oseltamivir Phosphate and Azithromycin for Influenza: A Multicenter, Open-Label, Randomized Study. Plos One 2014; 9: e9129346. doi:10.1371/journal.pone.0091293.

[57] Lee N, Wong CK, Chan MCW, Yeung ESL, Tam WWS, Tsang OTY, et al. Anti-inflammatory effects of adjunctive macrolide treatment in adults hospitalized with influenza: A randomized controlled trial. Antiviral Res 2017;144:48-56. doi:10.1016/j.antiviral.2017.05.008.

[58] Bermejo-Martin JF, Kelvin DJ, Eiros JM, Castrodeza J, De Lejarazu RO. Macrolides for the treatment of severe respiratory illness caused by novel H1N1 swine influenza viral strains. J Infect Dev Ctries 2009;3:15961. doi:10.3855/jidc.18.

[59] Gibson PG, Yang IA, Upham JW, Reynolds PN, Hodge S, James AL, et al. Effect of azithromycin on asthma exacerbations and quality of life in adults with persistent uncontrolled asthma (AMAZES): a randomised, double-blind, placebo-controlled trial. Lancet 2017;390:659-68. doi:10.1016/S0140-6736(17)31281-3.

[60] Hill AT, Sullivan AL, Chalmers JD, De Soyza A, Elborn JS, Floto RA, et al. British Thoracic Society Guideline for bronchiectasis in adults. Thorax 2019; 74: 1-69 doi:10.1136/thoraxjnl-2018-212463.

[61] Metlay JP, Waterer GW, Long AC, Anzueto A, Brozek J, Crothers K, et al. Diagnosis and Treatment of Adults with Community-acquired Pneumonia. An Official Clinical Practice Guideline of the American Thoracic Society and Infectious Diseases Society of America. Am J Respir Crit Car Med 2020; 200: e45-67.

[62] Martinez JA, Horcajada JP, Almela M, Marco F, Soriano A, Garcia E, et al. Addition of a Macrolide to a $\beta$-Lactam-Based Empirical Antibiotic Regimen Is Associated with Lower In-Hospital Mortality for Patients with Bacteremic Pneumococcal Pneumonia. Clin Infect Dis 2003;36:389-95. doi:10.1086/367541.

[63] Walkey AJ, Wiener RS. Macrolide antibiotics and survival in patients with acute lung injury. Chest 2012;141:1153-9. doi:10.1378/chest.11-1908.

[64] Touret F, Gilles M, Barral K, Nougairède A, Decroly E, Lamballerie X de, et al. In vitro screening of a FDA approved chemical library reveals potential inhibitors of SARS-CoV-2 replication. BioRxiv 2020:2020.04.03.023846. doi:10.1101/2020.04.03.023846.

[65] Andreani J, Le Bideau M, Duflot I, Jardot P, Rolland C, Boxberger M, et al. In vitro testing of combined hydroxychloroquine and azithromycin on SARS-CoV-2 shows synergistic effect. Microb Pathog 2020;145:0-3. doi:10.1016/j.micpath.2020.104228.

[66] Ulrich H, Pillat MM. CD147 as a Target for COVID-19 Treatment: Suggested Effects of Azithromycin and Stem Cell Engagement. Stem Cell Rev Rep. 2020;16(3):434-40. doi:10.1007/s12015-020-09976-7.

[67] Nujić K, Banjanac M, Munić V, Polančec D, Eraković Haber V. Impairment of lysosomal functions by azithromycin and chloroquine contributes to anti-inflammatory phenotype. Cell Immunol 2012;279:78-86. 
doi:10.1016/j.cellimm.2012.09.007.

[68] Tyteca D, Van Der Smissen P, Mettlen M, Van Bambeke F, Tulkens PM, Mingeot-Leclercq MP, et al. Azithromycin, a lysosomotropic antibiotic, has distinct effects on fluid-phase and receptor-mediated endocytosis, but does not impair phagocytosis in J774 macrophages. Exp Cell Res 2002;281:86-100. doi:10.1006/excr.2002.5613.

[69] Basque J, Martel M, Leduc R, Cantin AM. Lysosomotropic drugs inhibit maturation of transforming growth factor- $\beta$. Can J Physiol Pharmacol 2008;86:606-12. doi:10.1139/Y08-063.

[70] Markus Hoffmann HK-WSP. A multibasic cleavage site in the spike protein of SARS-CoV-2 is essential for infection of human lung cells. Cell Press 2020;78:779-784.e5. doi:10.1016/j.molcel.2020.04.022.

[71] Statement on IJAA paper | International Society of Antimicrobial Chemotherapy n.d. https://www.isac.world/news-and-publications/official-isac-statement (accessed May 23, 2020).

[72] Gautret P, Lagier J-C, Parola P, et al. Clinical and microbiological effect of a combination of hydroxychloroquine and azithromycin in 80 COVID-19 patients with at least a six-day follow up: an observational study. Travel Med Infect Dis 2020, in press.

[73] Million M, Lagier J-C, Gautret P, Colson P, Fournier P-E, Amrane S, et al. Full-length title: Early treatment of COVID-19 patients with hydroxychloroquine and azithromycin: A retrospective analysis of 1061 cases in Marseille, France. Travel Med Infect Dis 2020:101738. doi:10.1016/j.tmaid.2020.101738.

[74] Molina JM, Delaugerre C, Goff J Le, Mela-Lima B, Ponscarme D, Goldwirt L, et al. No Evidence of Rapid Antiviral Clearance or Clinical Benefit with the Combination of Hydroxychloroquine and Azithromycin in Patients with Severe COVID-19 Infection. Médecine Mal Infect 2020. doi:10.1016/j.medmal.2020.03.006.

[75] Mahévas M, Tran V-T, Roumier M, Chabrol A, Paule R, Guillaud C, et al. Clinical efficacy of hydroxychloroquine in patients with covid-19 pneumonia who require oxygen: observational comparative study using routine care data. BMJ 2020, in press. doi:10.1136/bmj.m1844.

[76] Magagnoli J, Narendran S, Pereira F, Cummings TH, Hardin JW, Sutton SS, et al. Outcomes of hydroxychloroquine usage in United States veterans hospitalized with COVID-19. MED. 2020, in press. doi:10.1016/j.medj.2020.06.001.

[77] Geleris J, Sun Y, Platt J, Zucker J, Baldwin M, Hripcsak G, et al. Observational Study of Hydroxychloroquine in Hospitalized Patients with Covid-19. N Engl J Med 2020:1-8. doi:10.1056/NEJMoa2012410.

[78] Rosenberg ES, Dufort EM, Udo T, Wilberschied LA, Kumar J, Tesoriero J, et al. Association of Treatment With Hydroxychloroquine or Azithromycin With In-Hospital Mortality in Patients With COVID-19 in New York State. Jama 2020;12203:1-10. doi:10.1001/jama.2020.8630.

[79] Guérin V, Lévy P, Thomas J-L, Lardenois T, Lacrosse P, Sarrazin E, et al. Azithromycin and Hydroxychloroquine Accelerate Recovery of Outpatients with Mild/Moderate COVID-19 Preprints. 2020, in press. doi:10.20944/PREPRINTS202005.0486.V1.

[80] Barbosa Esper R, Souza da Silva R, Teiichi Costa Oikawa F, Machado Castro M, Razuk-Filho A, Benedito Batista Junior P, et al. Empirical treatment with hydroxychloroquine and azithromycin for suspected cases of COVID-19 followed-up by telemedicine. Available at: https://pgibertie.files.wordpress.com/2020/04/2020.04.15-journal-manuscript-final.pdf.

[81] Mercuro NJ, Yen CF, Shim DJ, Maher TR, McCoy CM, Zimetbaum PJ, et al. Risk of QT Interval Prolongation Associated With Use of Hydroxychloroquine With or Without Concomitant Azithromycin Among Hospitalized Patients Testing Positive for Coronavirus Disease 2019 (COVID-19). JAMA Cardiol 2020:1-6. doi:10.1001/jamacardio.2020.1834.

[82] Chorin E, Dai M, Shulman E, Wadhwani L, Bar-Cohen R, Barbhaiya C, et al. The QT interval in patients 
with COVID-19 treated with hydroxychloroquine and azithromycin. Nat Med 2020:1-2. doi:10.1038/s41591020-0888-2.

[83] Bessière F, Roccia H, Delinière A, Charrière R, Chevalier P, Argaud L, et al. Assessment of QT Intervals in a Case Series of Patients With Coronavirus Disease 2019 (COVID-19) Infection Treated With Hydroxychloroquine Alone or in Combination With Azithromycin in an Intensive Care Unit. JAMA Cardiol 2020. doi:10.1001/jamacardio.2020.1787.

[84] Chang D, Saleh M, Gabriels J, Ismail H, Goldner B, Willner J, et al. Journal Pre-proof Inpatient Use of Ambulatory Telemetry Monitors for COVID-19 Patients Treated with Hydroxychloroquine and/or Azithromycin. J Am Coll Cardiol 2020, in press. doi:10.1016/j.jacc.2020.04.032.

[85] Chorin E, Wadhwani L, Magnani S, Dai M, Shulman E, Nadeau-Routhier C, et al. Journal Pre-proof QT Interval Prolongation and Torsade De Pointes in Patients with COVID-19 treated with Hydroxychloroquine/Azithromycin. Heart Rhythm 2020; S1547-5271:30435-5. doi:10.1016/j.hrthm.2020.05.014.

[86] Lane JC., Weaver J, Kostka K, Duarte-Salles T, Abrahao MTF, Alghoul H, et al. Safety of hydroxychloroquine, alone and in combination with azithromycin, in light of rapid wide-spread use for COVID-19: a multinational, network cohort and self-controlled case series study. MedRxiv. 2020:2020.04.08.20054551. doi:10.1101/2020.04.08.20054551.

[87] Harvey A. Risch. Early Outpatient Treatment of Symptomatic, High-Risk Covid-19 Patients that Should be Ramped-Up Immediately as Key to the Pandemic Crisis. Am J Epidemiol 2020;8034.

[88] Giudicessi JR, Noseworthy PA, Friedman PA, Ackerman MJ. Urgent Guidance for Navigating and Circumventing the QTc-Prolonging and Torsadogenic Potential of Possible Pharmacotherapies for Coronavirus Disease 19 (COVID-19). Mayo Clinic Proceedings 2020; 6:1213-21.

[89] Rubin EJ, Harrington DP, Hogan JW, Gatsonis C, Baden LR, Hamel MB. The Urgency of Care during the Covid-19 Pandemic — Learning as We Go. N Engl J Med 2020:NEJMe2015903. doi:10.1056/NEJMe2015903.

[90] Fadel, D.O, Austin R Morrison,Amit Vahia, et al. Early Short Course Corticosteroids in Hospitalized Patients with COVID-19. Clinical Infectious Diseases. 2020, in press.

[91] Tang N, Bai H, Chen X, Gong J, Li D, Sun Z. Anticoagulant treatment is associated with decreased mortality in severe coronavirus disease 2019 patients with coagulopathy. J Thromb Haemost 2020;18. doi:10.1111/jth.14817.

[92] Albert RK, Schuller JL. Macrolide antibiotics and the risk of cardiac arrhythmias. Am J Respir Crit Care Med 2014;189:1173-80. doi:10.1164/rccm.201402-0385CI.

[93] Wilson JG, Simpson LJ, Ferreira A-M, Rustagi A, Roque J, Asuni A, et al. Cytokine profile in plasma of severe COVID-19 does not differ from ARDS and sepsis. medRxiv 2020. https://doi.org/10.1101/2020.05.15.20103549. n.d. doi:10.1101/2020.05.15.20103549.

[94] Lansbury L, Lim B, Baskaran V, Lim WS. Journal Pre-proof Co-infections in people with COVID-19: a systematic review and meta-analysis Co-infections in people with COVID-19: a systematic review and meta-analysis. J Infect 2020. doi:10.1016/j.jinf.2020.05.046. 


\begin{tabular}{|c|c|c|c|c|c|c|}
\hline Ref. & $\begin{array}{l}\text { Design and } \\
\text { location }\end{array}$ & $\begin{array}{l}\text { Severity, \% } \\
\text { or mean } \\
\text { value }\end{array}$ & Virus & $\begin{array}{l}\text { Treatment } \\
\text { regimen } \\
(\mathrm{mg})\end{array}$ & $\begin{array}{l}\text { Number of } \\
\text { patients }\end{array}$ & Main results \\
\hline Lee et al.[57] & $\begin{array}{l}\text { Multicenter, } \\
\text { randomized } \\
\text { open-label } \\
\text { controlled } \\
\text { trial, China }\end{array}$ & $\begin{array}{l}\text { Supplemental } \\
\text { oxygen: } 32 \\
\text { Mechanical } \\
\text { ventilation: } 4\end{array}$ & $\begin{array}{l}\text { Influenza A } \\
\text { (H3N2) } \\
\text { (H1N1) } \\
\text { Influenza B }\end{array}$ & $\begin{array}{l}\text { OR } 500 \text { OD } \\
\text { for } 5 \text { days }\end{array}$ & $\begin{array}{l}\text { AZT + OST: } \\
25 \text { OST: } 25\end{array}$ & $\begin{array}{l}\text { At day } 10: \\
\text { IL-6: }-83.4 \% \\
\text { vs. }-59.5 \%, \\
\mathrm{P}=0.017 \\
\text { IL-17 }:-74.0 \\
\% \text { vs. }-34.3 \% \text {, } \\
\mathrm{P}=0.011 \\
\text { CXCL9/MIG : } \\
-71.3 \% \text { vs. } \\
-56.0 \%, \\
\mathrm{P}=0.031 \mathrm{CRP}: \\
-77.5 \% \text { vs. } \\
-48.2 \%, \\
\mathrm{P}=0.171\end{array}$ \\
\hline $\begin{array}{l}\text { Kakeya et al. } \\
{[56]}\end{array}$ & $\begin{array}{l}\text { Multicenter, } \\
\text { randomized } \\
\text { open-label } \\
\text { clinical trial, } \\
\text { Hong-Kong }\end{array}$ & Not reported & $\begin{array}{l}\text { Influenza A } \\
\text { (H1N1) }\end{array}$ & $\begin{array}{l}\text { OR } 2,000 \\
\text { extended- } \\
\text { release } \\
\text { single-dose }\end{array}$ & $\begin{array}{l}\text { AZT + OST: } \\
56 \text { OST: } 51\end{array}$ & $\begin{array}{l}\text { Improvement } \\
\text { in sore throat } \\
\text { at day } 2 \\
(\mathrm{P}=0.03) \\
\text { Decrease in } \\
\text { the maximum } \\
\text { temperature } \\
\text { on day } 4 \\
(\mathrm{P}=0.037) \\
\text { Maximum } \\
\text { temperature } \\
\text { on day } 3-5 \\
\text { significantly } \\
\text { lower } \\
(\mathrm{P}=0.048)\end{array}$ \\
\hline $\begin{array}{l}\text { Martin- } \\
\text { Loeches et } \\
\text { al. [53] }\end{array}$ & $\begin{array}{l}\text { Multicenter, } \\
\text { prospective } \\
\text { observational } \\
\text { cohort study, } \\
\text { Spain }\end{array}$ & $\begin{array}{l}\text { ICU } \\
\text { admission: } 100 \\
\text { APACHE II: } \\
14.3\end{array}$ & $\begin{array}{l}\text { Influenza A } \\
\text { (H1N1) }\end{array}$ & NR & $\begin{array}{l}\text { Macrolides: } \\
190 \text { CLT: } 99 \\
\text { (52.1) AZT: } \\
90 \text { (47.4) No } \\
\text { macrolides: } \\
543\end{array}$ & $\begin{array}{l}\text { ICU mortality } \\
\text { rate: aOR: } \\
0.89 \text { (95\% CI } \\
0.53-1.49) \text { ICU } \\
\text { mortality rate } \\
\text { in } \\
\text { mechanically } \\
\text { ventilated: } \\
\text { aOR: } 0.77 \text { (95 } \\
\text { \% CI } \\
0.44-1.35)\end{array}$ \\
\hline
\end{tabular}




\begin{tabular}{|c|c|c|c|c|c|c|}
\hline Ref. & $\begin{array}{l}\text { Design and } \\
\text { location }\end{array}$ & $\begin{array}{l}\text { Severity, \% } \\
\text { or mean } \\
\text { value }\end{array}$ & Virus & $\begin{array}{l}\text { Treatment } \\
\text { regimen } \\
(\mathrm{mg})\end{array}$ & $\begin{array}{l}\text { Number of } \\
\text { patients }\end{array}$ & Main results \\
\hline $\begin{array}{l}\text { Ishaqui et al. } \\
\text { [55] }\end{array}$ & $\begin{array}{l}\text { Multicenter, } \\
\text { retrospective } \\
\text { observational } \\
\text { cohort study, } \\
\text { Saudi Arabia }\end{array}$ & $\begin{array}{l}\text { Lymphocytes: } \\
240 \text { x } 10^{9} \\
\text { Albumin: } 4.1 \\
\text { g/dL }\end{array}$ & $\begin{array}{l}\text { Influenza A } \\
\text { (H1N1) }\end{array}$ & $\begin{array}{l}\text { OR/IV } 500 \\
\text { (duration } \\
\text { unknown) }\end{array}$ & $\begin{array}{l}\text { AZT + OST: } \\
102 \text { OST: } 227\end{array}$ & $\begin{array}{l}\text { Secondary } \\
\text { bacterial } \\
\text { infections: } \\
\text { aOR: 0.285 (95 } \\
\text { \% CI, 0.1-0.81) } \\
\text { Respiratory } \\
\text { support during } \\
\text { hospitaliza- } \\
\text { tion: aOR: } \\
\text { 0.28 (95 \% CI, } \\
\text { 0.09-0.786) } \\
\text { Length of } \\
\text { hospital stay: } \\
\text { aOR: 0.21 (95 } \\
\text { \% CI, } \\
\text { 0.14-0.31) } \\
\text { Influenza } \\
\text { symptom } \\
\text { severity score } \\
\text { day 5: aOR: } \\
\text { 0.67 (95 \% CI, } \\
0.57-0.87)\end{array}$ \\
\hline Arabi et al. [54] & $\begin{array}{l}\text { Multicenter, } \\
\text { retrospective } \\
\text { observational } \\
\text { cohort study, } \\
\text { Saudi Arabia }\end{array}$ & $\begin{array}{l}\text { SOFA: } 9 \\
\text { Mechanical } \\
\text { ventilation: } \\
61.8\end{array}$ & MERS-CoV & NR & $\begin{array}{l}\text { Macrolides: } \\
\text { 136 AZT: 97 } \\
\text { (71.3) CLT: } \\
\text { 28 (20.6) } \\
\text { ERT: 22 } \\
\text { (16.1) No } \\
\text { macrolides: } \\
213\end{array}$ & $\begin{array}{l}\text { 90-day } \\
\text { mortality: } \\
\text { aOR: } 0.84(95 \\
\text { \% CI } \\
0.47-1.51) \\
\text { RNA } \\
\text { clearance: } \\
\text { aHR: } 0.88 \text { (95 } \\
\text { \% CI } \\
0.47-1.64)\end{array}$ \\
\hline
\end{tabular}

Table 1: Clinical efficacy of azithromycin in viral infections.

OR: oral; OD: once daily; AZT: Azithromycin; OST: oseltamivir; IL: interleukins; CRP: C-reactive protein; aOR: adjusted odds ratio; IV: intravenous; APACHE II: Acute Physiology and Chronic Health Disease Classification; NR: not reported; SOFA: Sequential Organ Failure Assessment; MERS-CoV: Middle East Respiratory Syndrome coronavirus; CLT: Clarithromycin; ERT: erythromycin.

Table 2: Clinical studies of azithromycin for the treatment of COVID-19. 


\begin{tabular}{|c|c|c|c|c|c|c|c|}
\hline Ref. & $\begin{array}{l}\text { Design } \\
\text { and } \\
\text { location }\end{array}$ & $\begin{array}{l}\text { Comorbidities, } \\
\%\end{array}$ & $\begin{array}{l}\text { Severity, } \\
\%\end{array}$ & $\begin{array}{l}\text { Days from } \\
\text { symptoms } \\
\text { onset }\end{array}$ & $\begin{array}{l}\text { Treatment } \\
\text { regimen } \\
(\mathrm{mg})\end{array}$ & $\begin{array}{l}\text { Number of } \\
\text { patients }\end{array}$ & $\begin{array}{l}\text { Main } \\
\text { results }\end{array}$ \\
\hline \multirow[t]{2}{*}{$\begin{array}{l}\text { Gautret et } \\
\text { al. }[8]\end{array}$} & $\begin{array}{l}\text { Multicenter, } \\
\text { open-label, } \\
\text { non- } \\
\text { randomized } \\
\text { CT, France }\end{array}$ & $\begin{array}{l}\text { HBP: NR } \\
\text { Diabetes: } \\
\text { NR Obesity: } \\
\text { NR }\end{array}$ & $\begin{array}{l}\text { Asymptomatic: } \\
16.7 \text { URTI } \\
\text { symptoms: } \\
61.1\end{array}$ & & $\begin{array}{l}500 \text { day } 1, \\
250 \text { OD days } \\
2-5\end{array}$ & & $\begin{array}{l}P C R \\
\text { negative day } \\
6(P=0.001)\end{array}$ \\
\hline & & & & & & $\begin{array}{l}\text { HCQ: } 20 \\
\text { HCQ + } \\
\text { AZT: } 6 \\
\text { SOC: } 16\end{array}$ & $\begin{array}{l}57.1 \% \\
100 \% \\
12.5 \%\end{array}$ \\
\hline $\begin{array}{l}\text { Gautret et } \\
\text { al. }[72]\end{array}$ & $\begin{array}{l}\text { Single } \\
\text { center, ret- } \\
\text { rospective, } \\
\text { observa- } \\
\text { tional study, } \\
\text { France }\end{array}$ & $\begin{array}{l}\text { HBP: } 16 \\
\text { Diabetes: } 11 \\
\text { Obesity: } 5\end{array}$ & $\begin{array}{l}\text { Asymptomatic: } \\
5.0 \text { URTI } \\
\text { symptoms: } \\
41.2 \text { NEWS } \\
\text { low (0-4): } 92\end{array}$ & & $\begin{array}{l}500 \text { day } 1, \\
250 \text { OD days } \\
2-5\end{array}$ & $\begin{array}{l}\mathrm{HCQ}+ \\
\mathrm{AZT}: 80\end{array}$ & $\begin{array}{l}\text { Day 7: } 81 \% \\
\text { clinical cure } \\
3.8 \% \\
\text { transferred } \\
\text { to ICU } 83 \% \\
\text { PCR } \\
\text { negative }\end{array}$ \\
\hline $\begin{array}{l}\text { Million et } \\
\text { al. [73] }\end{array}$ & $\begin{array}{l}\text { Single } \\
\text { center, ret- } \\
\text { rospective, } \\
\text { observa- } \\
\text { tional study, } \\
\text { France }\end{array}$ & $\begin{array}{l}\text { HBP: } 14 \\
\text { Diabetes: } 7 \\
\text { Obesity: } 6\end{array}$ & $\begin{array}{l}\text { NEWS low } \\
(0-4): 95\end{array}$ & 6 & $\begin{array}{l}500 \text { day } 1, \\
250 \text { OD days } \\
2-5\end{array}$ & $\begin{array}{l}\text { HQC }+ \\
\text { AZT: } 1,061\end{array}$ & $\begin{array}{l}\text { Day 7: } 91.7 \\
\% \text { clinical } \\
\text { and } \\
\text { virological } \\
\text { cure } 0.9 \% \\
\text { transferred } \\
\text { to ICU } 0.8 \\
\% \text { died }\end{array}$ \\
\hline $\begin{array}{l}\text { Molina et } \\
\text { al. [74] }\end{array}$ & $\begin{array}{l}\text { Single } \\
\text { center, ret- } \\
\text { rospective, } \\
\text { observa- } \\
\text { tional study, } \\
\text { France }\end{array}$ & $\begin{array}{l}\text { HBP: NR } \\
\text { Diabetes: } \\
\text { NR Obesity: } \\
18 \text { Cancer: } \\
46\end{array}$ & NR & NR & $\begin{array}{l}500 \text { day } 1, \\
250 \text { OD days } \\
2-5\end{array}$ & $\begin{array}{l}\mathrm{HCQ}+ \\
\text { AZT: } 11\end{array}$ & $\begin{array}{l}\text { Day 5: } 9 \% \\
\text { died } 18.2 \% \\
\text { transferred } \\
\text { to ICU Day } \\
6: 80 \% \\
\text { PCR } \\
\text { positive }\end{array}$ \\
\hline \multirow[t]{2}{*}{$\begin{array}{l}\text { Mahevas et } \\
\text { al.[75] }\end{array}$} & $\begin{array}{l}\text { Multicenter, } \\
\text { retrospec- } \\
\text { tive, } \\
\text { propensity- } \\
\text { score } \\
\text { matched ob- } \\
\text { servational } \\
\text { study, } \\
\text { France }\end{array}$ & $\begin{array}{l}\text { HBP: } 51 \\
\text { Diabetes: } 9 \\
\text { Obesity: } 26\end{array}$ & $\begin{array}{l}>50 \% \\
\text { extend on } \\
\text { CT: } 33\end{array}$ & 7 & $\begin{array}{l}500 \text { day } 1, \\
250 \text { OD days } \\
2-5\end{array}$ & & $\begin{array}{l}\text { 21-day } \\
\text { mortality \% } \\
\text { and HR: }\end{array}$ \\
\hline & & & & & & $\begin{array}{l}\text { HCQ: } 84 \\
H C Q+ \\
A Z T: 15 \\
\text { Control: } 89 \\
\text { AZT: 26 } \\
\text { (29.2\%) }\end{array}$ & $\begin{array}{l}\text { HCQ: } 11 \% \text {, } \\
1.2 \text { (95 \% CI } \\
0.4-3.3) \\
\text { Control: } 9 \\
\% \text {. } \\
\text { Reference }\end{array}$ \\
\hline
\end{tabular}




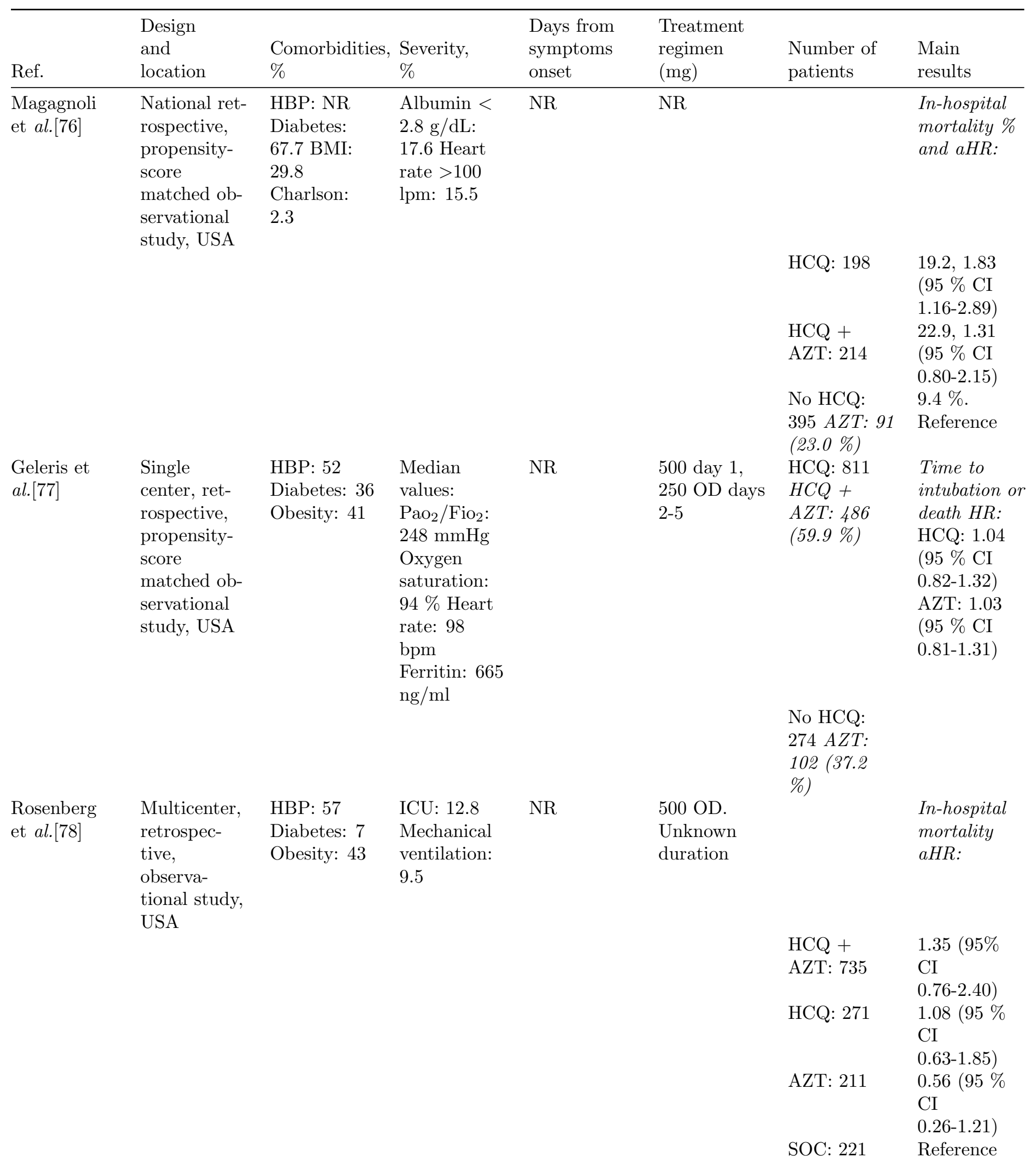




\begin{tabular}{|c|c|c|c|c|c|c|c|}
\hline Ref. & $\begin{array}{l}\text { Design } \\
\text { and } \\
\text { location }\end{array}$ & $\begin{array}{l}\text { Comorbidities, } \\
\%\end{array}$ & $\begin{array}{l}\text { Severity, } \\
\%\end{array}$ & $\begin{array}{l}\text { Days from } \\
\text { symptoms } \\
\text { onset }\end{array}$ & $\begin{array}{l}\text { Treatment } \\
\text { regimen } \\
(\mathrm{mg})\end{array}$ & $\begin{array}{l}\text { Number of } \\
\text { patients }\end{array}$ & $\begin{array}{l}\text { Main } \\
\text { results }\end{array}$ \\
\hline \multirow{7}{*}{$\begin{array}{l}\text { Guerin et } \\
a l .[79]\end{array}$} & \multirow{7}{*}{$\begin{array}{l}\text { Retrospective, } \\
\text { observa- } \\
\text { tional study, } \\
\text { France }\end{array}$} & \multirow{7}{*}{$\begin{array}{l}\text { HBP: } 12.8 \\
\text { Diabetes: } \\
3.4 \text { Obesity: } \\
13.6\end{array}$} & \multirow[t]{7}{*}{ Outpatients } & \multirow{7}{*}{$\begin{array}{l}1(41 \%) \\
\text { Within } 15 \\
(57.9)\end{array}$} & \multirow{7}{*}{$\begin{array}{l}500 \text { day } 1, \\
250 \text { OD days } \\
2-5\end{array}$} & & Time to \\
\hline & & & & & & & clinical \\
\hline & & & & & & & recovery, \\
\hline & & & & & & & median \\
\hline & & & & & & $\begin{array}{l}\mathrm{HCQ}+ \\
\mathrm{AZT}: 20\end{array}$ & $\begin{array}{l}\text { (range): } \\
7(2-40)\end{array}$ \\
\hline & & & & & & AZT: 34 & $7(3-48)$ \\
\hline & & & & & & SOC: 34 & $27(6-48)$ \\
\hline \multirow{6}{*}{$\begin{array}{l}\text { Barbosa et } \\
\text { al. }[80]\end{array}$} & \multirow{6}{*}{$\begin{array}{l}\text { Open label, } \\
\text { controlled } \\
\text { non- } \\
\text { randomized } \\
\text { trial, Brazil }\end{array}$} & \multirow{6}{*}{$\begin{array}{l}\text { HBP: } 26.5 \\
\text { Diabetes: } \\
13.4 \\
\text { Obesity: } 7.7\end{array}$} & \multirow[t]{6}{*}{ Outpatients } & \multirow[t]{6}{*}{$5.2 \pm 3.1$} & \multirow{6}{*}{$\begin{array}{l}500 \text { OD } 5 \\
\text { days }\end{array}$} & & Need for \\
\hline & & & & & & & hospitaliza- \\
\hline & & & & & & & tion \\
\hline & & & & & & & \\
\hline & & & & & & $\begin{array}{l}\text { HCQ+AZT: } \\
412\end{array}$ & $1.9 \%$ \\
\hline & & & & & & SOC: 224 & $5.4 \%$ \\
\hline
\end{tabular}

CT: Clinical trial; AZT: Azithromycin; HBP: high blood pressure; NR: not reported; URTI: upper respiratory tract infections; OD: once daily; HCQ: hydroxychloroquine; SOC: standard of care; PCR: polymerase chain reaction; NEWS: National Early Warning Score; ICU: intensive care unit; HR: hazard ratio; CI: confidence interval; CT: computed tomography scan; MCR: macrolide; CLT: clarithromycin; BMI; body mass index, $\mathrm{kg} / \mathrm{m}^{2}$.

Table 3: Cardiovascular safety data on the use of azithromycin alone or in combination for the treatment of COVID-19.

\begin{tabular}{|c|c|c|c|c|c|c|c|}
\hline Ref. & $\begin{array}{l}\text { Design } \\
\text { and } \\
\text { location }\end{array}$ & $\begin{array}{l}\text { Treatment } \\
\text { regimen } \\
(\mathrm{mg})\end{array}$ & $\begin{array}{l}\text { Number of } \\
\text { patients }\end{array}$ & $\begin{array}{l}\Delta \mathrm{QTc} \\
(\mathrm{ms})\end{array}$ & $\begin{array}{l}\text { Clinical } \\
\text { outcome } \\
\text { (arrhyth- } \\
\text { mia, } \\
\text { TdP) }\end{array}$ & $\begin{array}{l}\text { Clinical } \\
\text { outcome } \\
\text { (arrhyth- } \\
\text { mia, } \\
\text { TdP) }\end{array}$ & $\begin{array}{l}\text { Treatment } \\
\text { discontinuatio }\end{array}$ \\
\hline \multirow[t]{3}{*}{$\begin{array}{l}\text { Saleh et } \\
\text { al.[28] }\end{array}$} & $\begin{array}{l}\text { Multicenter, } \\
\text { prospec- } \\
\text { tive, } \\
\text { observa- } \\
\text { tional } \\
\text { study, } \\
\text { USA }\end{array}$ & $\begin{array}{l}\text { OR/IV } \\
500 \text { OD } 5 \\
\text { days }\end{array}$ & & & $\begin{array}{l}\text { Ventricular } \\
\text { arrhyth- } \\
\text { mia }\end{array}$ & $\begin{array}{l}\text { Ventricular } \\
\text { arrhyth- } \\
\text { mia }\end{array}$ & $\begin{array}{l}4.2 \% \text { due } \\
\text { to QTc } \\
\text { prolongation }\end{array}$ \\
\hline & & & $\begin{array}{l}\mathrm{HCQ}+ \\
\mathrm{AZT}: 119\end{array}$ & $\begin{array}{l}\text { Mean } \Delta: \\
27.5 \pm 44.3 \\
\text { QTc> } 500: \\
9.2 \%\end{array}$ & $5.0 \%$ & $5.0 \%$ & \\
\hline & & & HCQ: 82 & $\begin{array}{l}\text { Mean } \Delta: 3.9 \\
\pm 32.9 \\
\text { QTc> } 500: \\
8.6 \%\end{array}$ & $2.4 \%$ & $2.4 \%$ & $\begin{array}{l}2.4 \% \text { due to } \\
\text { QTc } \\
\text { prolongation }\end{array}$ \\
\hline
\end{tabular}




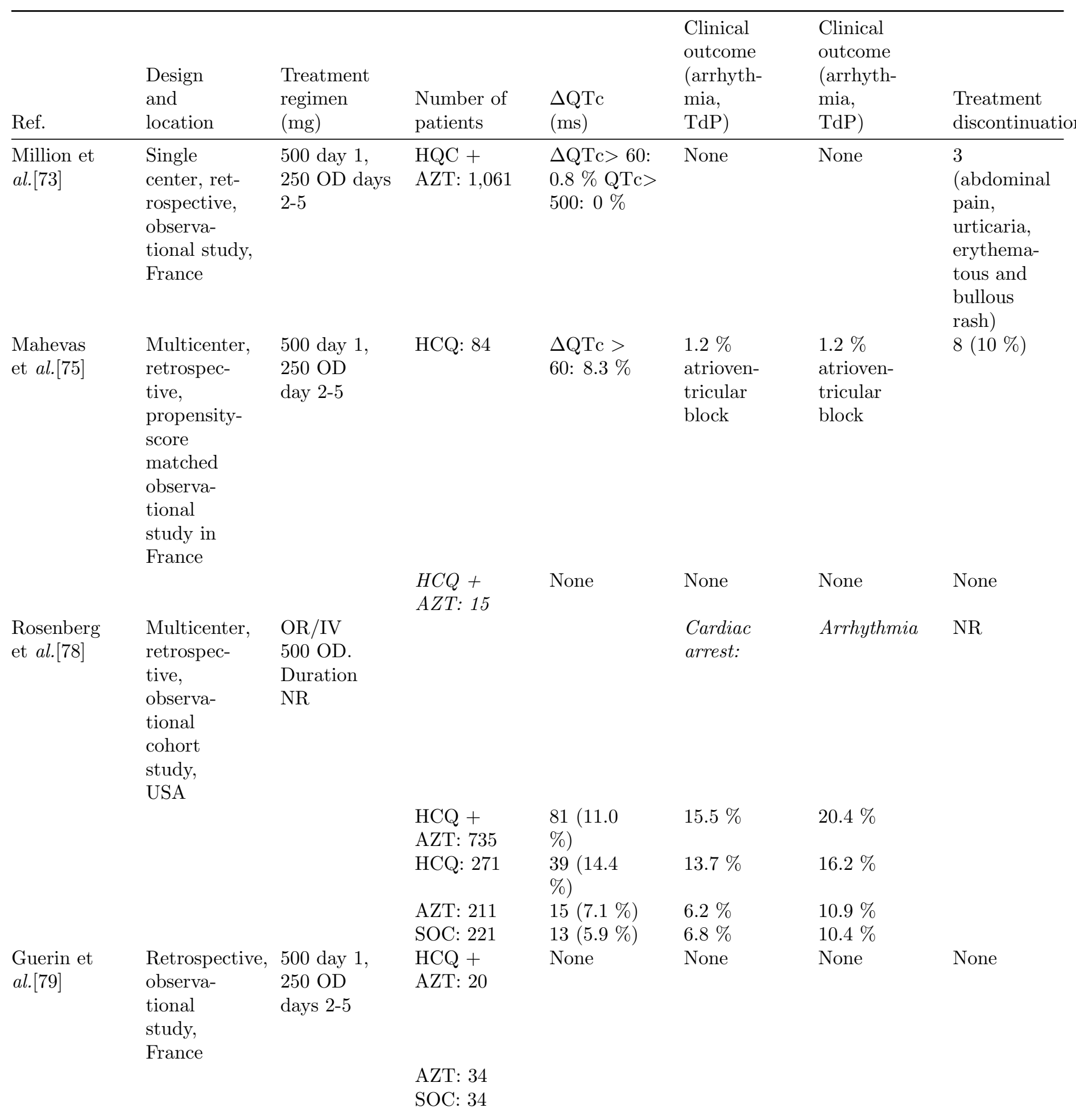




\begin{tabular}{|c|c|c|c|c|c|c|c|}
\hline Ref. & $\begin{array}{l}\text { Design } \\
\text { and } \\
\text { location }\end{array}$ & $\begin{array}{l}\text { Treatment } \\
\text { regimen } \\
(\mathrm{mg})\end{array}$ & $\begin{array}{l}\text { Number of } \\
\text { patients }\end{array}$ & $\begin{array}{l}\Delta \mathrm{QTc} \\
(\mathrm{ms})\end{array}$ & $\begin{array}{l}\text { Clinical } \\
\text { outcome } \\
\text { (arrhyth- } \\
\text { mia, } \\
\text { TdP) }\end{array}$ & $\begin{array}{l}\text { Clinical } \\
\text { outcome } \\
\text { (arrhyth- } \\
\text { mia, } \\
\text { TdP) }\end{array}$ & $\begin{array}{l}\text { Treatment } \\
\text { discontinuatio }\end{array}$ \\
\hline $\begin{array}{l}\text { Barbosa } \\
\text { et } a l .[80]\end{array}$ & $\begin{array}{l}\text { Open } \\
\text { label, } \\
\text { controlled } \\
\text { non- } \\
\text { randomized } \\
\text { trial, } \\
\text { Brasil }\end{array}$ & $\begin{array}{l}500 \text { OD } 5 \\
\text { days }\end{array}$ & $\begin{array}{l}\text { HCQ+AZT: } \\
412\end{array}$ & None & None & None & None \\
\hline \multirow[t]{2}{*}{$\begin{array}{l}\text { Mercuro et } \\
a l .[81]\end{array}$} & $\begin{array}{l}\text { Single } \\
\text { center, ret- } \\
\text { rospective, } \\
\text { observa- } \\
\text { tional } \\
\text { cohort, USA }\end{array}$ & NR & $\begin{array}{l}\text { SOC: } 224 \\
\text { HCQ }+ \\
\text { AZT: } 53\end{array}$ & $\begin{array}{l}\text { None } \\
\text { Mean } \Delta: 23 \\
(10-40) \\
\text { QTc> }>500: \\
21 \% \\
\Delta Q T c>60: \\
13 \%\end{array}$ & $\begin{array}{l}1 \text { extreme } \\
\text { QTc } \\
\text { prolongation } \\
\text { that } \\
\text { developed } \\
\text { TdP }\end{array}$ & $\begin{array}{l}1 \text { extreme } \\
\text { QTc } \\
\text { prolongation } \\
\text { that } \\
\text { developed } \\
\text { TdP }\end{array}$ & $\begin{array}{l}1.1 \% \text { due to } \\
\text { QTc } \\
\text { prolongation }\end{array}$ \\
\hline & & & HCQ: 37 & $\begin{array}{l}\text { Mean } \Delta: 5.5 \\
(-14-31) \\
\text { QTc> }>00: \\
19 \% \\
\Delta \text { QTc > 60: } \\
3 \%\end{array}$ & None & None & $\begin{array}{l}11.1 \% \text { due } \\
\text { to QTc } \\
\text { prolongation }\end{array}$ \\
\hline $\begin{array}{l}\text { Chorin et } \\
a l .[82]\end{array}$ & $\begin{array}{l}\text { Single } \\
\text { center, ret- } \\
\text { rospective, } \\
\text { observa- } \\
\text { tional } \\
\text { cohort, USA }\end{array}$ & $\begin{array}{l}500 \text { OD. } \\
\text { Duration } \\
\text { NR }\end{array}$ & $\begin{array}{l}\mathrm{HQC}+ \\
\mathrm{AZT}: 84\end{array}$ & $\begin{array}{l}\text { QTc> 500: } \\
11 \% \\
\Delta \mathrm{QTc}>60: \\
12 \%\end{array}$ & None & None & NR \\
\hline \multirow[t]{2}{*}{$\begin{array}{l}\text { Bessiere et } \\
a l .[83]\end{array}$} & $\begin{array}{l}\text { Single } \\
\text { center, } \\
\text { retrospec- } \\
\text { tive, } \\
\text { observa- } \\
\text { tional } \\
\text { cohort } \\
\text { study }\end{array}$ & $\begin{array}{l}250 \text { OD } 5 \\
\text { days }\end{array}$ & $\begin{array}{l}\mathrm{HCQ}+ \\
\text { AZT: } 18\end{array}$ & $\begin{array}{l}\text { QTc }> \\
500: 33 \%\end{array}$ & None & None & NR \\
\hline & & & HCQ: 22 & $\begin{array}{l}\text { QTc }> \\
500: 5 \%\end{array}$ & & & \\
\hline \multirow[t]{2}{*}{$\begin{array}{l}\text { Chang et } \\
\text { al. [84] }\end{array}$} & $\begin{array}{l}\text { Single } \\
\text { center, } \\
\text { prospective } \\
\text { observa- } \\
\text { tional cohort } \\
\text { study, USA }\end{array}$ & $\begin{array}{l}\text { At least } 1 \\
\text { dose IV } 500\end{array}$ & $\begin{array}{l}\mathrm{HCQ}+ \\
\text { AZT: } 51\end{array}$ & $\begin{array}{l}\text { Mean } \Delta \text { : } \\
12.8 \pm 29.3\end{array}$ & $\begin{array}{l}\text { Atrial } \\
\text { fibrillation: } \\
12.8 \% \\
\text { Supraven- } \\
\text { tricular } \\
\text { tachycardia: } \\
0.9 \%\end{array}$ & $\begin{array}{l}\text { Atrial } \\
\text { fibrillation: } \\
12.8 \% \\
\text { Supraven- } \\
\text { tricular } \\
\text { tachycardia: } \\
0.9 \%\end{array}$ & None \\
\hline & & & HCQ: 66 & $\begin{array}{l}\text { Mean } \Delta: \\
3.9 \pm 31.9\end{array}$ & & & $\begin{array}{l}1.5 \% \text { due } \\
\text { to QTc } \\
\text { prolongation }\end{array}$ \\
\hline
\end{tabular}




\begin{tabular}{|c|c|c|c|c|c|c|c|}
\hline Ref. & $\begin{array}{l}\text { Design } \\
\text { and } \\
\text { location }\end{array}$ & $\begin{array}{l}\text { Treatment } \\
\text { regimen } \\
(\mathrm{mg})\end{array}$ & $\begin{array}{l}\text { Number of } \\
\text { patients }\end{array}$ & $\begin{array}{l}\Delta \mathrm{QTc} \\
(\mathrm{ms})\end{array}$ & $\begin{array}{l}\text { Clinical } \\
\text { outcome } \\
\text { (arrhyth- } \\
\text { mia, } \\
\text { TdP) }\end{array}$ & $\begin{array}{l}\text { Clinical } \\
\text { outcome } \\
\text { (arrhyth- } \\
\text { mia, } \\
\text { TdP) }\end{array}$ & $\begin{array}{l}\text { Treatment } \\
\text { discontinuatio }\end{array}$ \\
\hline $\begin{array}{l}\text { Chorin et } \\
a l .[85]\end{array}$ & $\begin{array}{l}\text { Multicenter, } \\
\text { observa- } \\
\text { tional study } \\
\text { in Italy and } \\
\text { USA }\end{array}$ & $\begin{array}{l}\text { OR } 500 \text { OD } \\
5 \text { days }\end{array}$ & $\begin{array}{l}\mathrm{HCQ}+ \\
\text { AZT: } 251\end{array}$ & $\begin{array}{l}\text { Mean } \Delta: 34 \\
\pm 30 \text { QTc }> \\
500: 20 \% \\
\text { Extreme } \\
\text { QTc prolon- } \\
\text { gation: } 23 \\
\%\end{array}$ & NR & NR & $\begin{array}{l}3.2 \% \text { due to } \\
\text { QTc } \\
\text { prolongation }\end{array}$ \\
\hline $\begin{array}{l}\text { Lane et } \\
a l .[86]\end{array}$ & $\begin{array}{l}\text { Multinational, } \\
\text { network } \\
\text { cohort and } \\
\text { self- } \\
\text { controlled } \\
\text { case study }\end{array}$ & NR & $\begin{array}{l}\text { HCQ } \\
+\mathrm{AZT}: \\
323,122 \\
\mathrm{HCQ}+ \\
\text { AMX: } \\
351,956\end{array}$ & $\mathrm{NR}$ & $\begin{array}{l}\text { 30-day car- } \\
\text { diovascular } \\
\text { mortality } \\
\text { CalHR: } 2.19 \\
(95 \% \text { CI } \\
1.22-3.94) \\
\text { Chest } \\
\text { pain/angina } \\
\text { CalHR: } 1.15 \\
(95 \% \text { CI } \\
1.05-1.26) \\
\text { Heart failure } \\
\text { CalHR 1.22 } \\
\text { (95 \% CI } \\
1.02-1.45)\end{array}$ & $\begin{array}{l}\text { 30-day car- } \\
\text { diovascular } \\
\text { mortality } \\
\text { CalHR: } 2.19 \\
(95 \% \text { CI } \\
1.22-3.94) \\
\text { Chest } \\
\text { pain/angina } \\
\text { CalHR: } 1.15 \\
(95 \% \text { CI } \\
1.05-1.26) \\
\text { Heart failure } \\
\text { CalHR 1.22 } \\
\text { (95\% CI } \\
1.02-1.45)\end{array}$ & NR \\
\hline
\end{tabular}

TdP: Torsade de Pointes; HCQ: hydroxychloroquine; AZT: azithromycin; BID: twice daily; OD: once daily; NR: not reported; MCR: macrolides; CLT: clarithromycin; HR: hazard ratio; CI: confidence interval; AMX: amoxicillin; CalHR: calibrated hazard ratio

Hydroxychloroquine was administered orally. Azithromycin data on route administration was lacking except stating otherwise.

$\triangle$ QTc: the increment was reported either in milliseconds, number of patients (percentage) with increment in QTc, number of patients (percentage) with increment of QTc $>60 \mathrm{~ms}$, number of patients (percentage) with QTc > $500 \mathrm{~ms}$.

\section{Figure legends:}

1. SARS-CoV-2 binding: the increase in the $\mathrm{pH}$ of Trans-Golgi network may alter hACE2 glycosilation. Azithromycin resulted in a ganglioside-mimic given its similar volume and analogous chemical features than GM1. Since the spike protein of SARS-CoV-2 displays a ganglioside-binding site, azithromycin might inhibit SARS-CoV-2 infection by binding to this site. It may also interfere with ligand CD147 receptor interactions.

2. Membrane fusion, endocytosis, and lysosomal protease activation: the increase in lysosomal $\mathrm{pH}$ impairs the endocytosis process and the action of essential lysosomal proteases, as cathepsins or furins, implicated in the cleavage of the spike protein of SARS-CoV-2.

3. Reduction of pro-inflammatory cytokines and chemokines production: (IL-1 $\beta$, IL-6, IL-8, IL-12, IFN- $\gamma$, IP-10, TNF- $\alpha$, and GM-CSF).

4. Lymphocytes: suppression of CD4+ T-cell activation. 
5. Alveolar macrophages: shift in the polarization to anti-inflammatory phenotype and increase apoptosis.

6. Fibroblasts: antifibrotic activity: inhibition of fibroblast proliferation, collagen production reduction, decrease transforming growth factor TGF- $\beta$ production, inhibition of TGF- $\beta$ induced pro-fibrotic gene stimulation.

7. Epithelial cells: stabilization of the cell membrane, increase in the transepithelial electrical barrier and induction of the processing of the tight junction proteins claudins and junctional adhesion molecule-A. Decrease mucus hypersecretion, which may improve mucociliary clearance.

\section{Hosted file}

Figure 1.docx available at https://authorea.com/users/331465/articles/458155-couldazithromycin-play-a-role-in-the-treatment-of-covid-19-a-review 